\title{
Can we reconstruct the formation of large open-ocean polynyas in the Southern Ocean using ice core records?
}

\author{
Hugues Goosse $^{1}$, Quentin Dalaiden ${ }^{1}$, Marie G. P. Cavitte ${ }^{1}$, and Liping Zhang ${ }^{2,3}$ \\ ${ }^{1}$ Earth and Life Institute, Université catholique de Louvain, Louvain-la-Neuve, Belgium \\ ${ }^{2}$ NOAA/Geophysical Fluid Dynamics Laboratory, Princeton, New Jersey, USA \\ ${ }^{3}$ Cooperative Programs for the Advancement of Earth System Science, University Corporation for Atmospheric \\ Research, Boulder, Colorado, USA
}

Correspondence: Hugues Goosse (hugues.goosse@uclouvain.be)

Received: 6 July 2020 - Discussion started: 10 August 2020

Revised: 4 November 2020 - Accepted: 13 November 2020 - Published: 12 January 2021

\begin{abstract}
Large open-ocean polynyas, defined as ice-free areas within the sea ice pack, have only rarely been observed in the Southern Ocean over the past decades. In addition to smaller recent events, an impressive sequence occurred in the Weddell Sea in 1974, 1975 and 1976 with openings of more than $300000 \mathrm{~km}^{2}$ that lasted the full winter. These big events have a huge impact on the sea ice cover, deep-water formation, and, more generally, on the Southern Ocean and the Antarctic climate. However, we have no estimate of the frequency of the occurrence of such large open-ocean polynyas before the 1970s. Our goal here is to test if polynya activity could be reconstructed using continental records and, specifically, observations derived from ice cores. The fingerprint of big open-ocean polynyas is first described in reconstructions based on data from weather stations, in ice cores for the 1970 s and in climate models. It shows a signal characterized by a surface air warming and increased precipitation in coastal regions adjacent to the eastern part of the Weddell Sea, where several high-resolution ice cores have been collected. The signal of the isotopic composition of precipitation is more ambiguous; thus, we base our reconstructions on surface mass balance records alone. A first reconstruction is obtained by performing a simple average of standardized records. Given the similarity between the observed signal and the one simulated in models, we also use data assimilation to reconstruct past polynya activity. The impact of open-ocean polynyas on the continent is not large enough, compared with the changes due to factors such as atmospheric variability, to detect the polynya signal without ambiguity, and additional observations would be required to clearly discriminate the
\end{abstract}

years with and without open-ocean polynya. Thus, it is reasonable to consider that, in these preliminary reconstructions, some high snow accumulation events may be wrongly interpreted as the consequence of polynya formation and some years with polynya formation may be missed. Nevertheless, our reconstructions suggest that big open-ocean polynyas, such as those observed in the 1970s, are rare events, occurring at most a few times per century. Century-scale changes in polynya activity are also likely, but our reconstructions are unable to precisely assess this aspect at this stage.

\section{Introduction}

Polynyas are ice-free oceanic areas within the sea ice pack. They are regularly observed close to the coasts of Antarctica where very strong winds coming from the continent push the sea ice away from the shore as soon as it is formed (Comiso and Gordon, 1987; Morales Maqueda et al., 2004). Open-ocean polynyas, which are polynyas that occur far from the coast, are rarer and, thus, much less known. Several short-lived open-ocean polynyas have been observed in the Southern Ocean over the last decades, with relatively large ones in the Weddell Sea in 2016 and 2017 reaching $50000 \mathrm{~km}^{2}$ (Comiso and Gordon, 1996; Swart et al., 2018; Jena et al., 2019; Campbell et al., 2019). In addition to those relatively short-lived events, the great Weddell Sea polynya (Fig. 1) of 1974, 1975 and 1976 was truly exceptional in historical records, both due to its size of $300000 \mathrm{~km}^{2}$, i.e., about 
10 times the size of Belgium, and the fact that it remained open all winter long (Carsey, 1980; Zwally et al., 1983).

In contrast to the coastal polynyas, wind alone is not sufficient to maintain open-ocean polynyas. A major oceanic heat source is required to sustain the large heat loss at the atmosphere-ocean interface and prevent sea ice formation (Morales Maqueda et al., 2004). In the Weddell Sea, this is achieved by open-ocean convection that continuously brings warmer water from the deeper oceanic layers to the surface (Gordon, 1978; Martinson et al., 1981). For the Weddell polynya of the 1970s, oceanic observations indicate mixing to a depth of $3000 \mathrm{~m}$ compared with a depth of about $100 \mathrm{~m}$ in normal years (Gordon, 1982). During the formation of the polynya in 2017 , the observed mixing reached a depth of more than $1700 \mathrm{~m}$ (Campbell et al., 2019).

Although the role of deep oceanic mixing appears crucial, the specific mechanisms leading to the formation of openocean polynya in the Southern Ocean are still under debate. Compared with other regions of the world, the stability of the water column is low in the Southern Ocean (Gordon and Huber, 1990; Martinson, 1990). The cold and relatively fresh surface water is separated from warmer water at depth by a relatively weak pycnocline. This warm deep water is supplied by an input from the Antarctic Circumpolar Current (the circumpolar deep water), which itself originates in the deep water formed in the North Atlantic. Nevertheless, the low stratification is maintained by strong sea-ice-ocean feedbacks (Martinson, 1990; Goosse et al., 2018; Wilson et al., 2019), and open convection reaching large depths is very rare.

Deep convection requires some preconditioning of the ocean, reducing the overall stability of the water column (Morales Maqueda et al., 2004; Dufour et al., 2017; Kurtakoti et al., 2018; Campbell et al., 2019). The opening of a polynya is then triggered by the winds and, specifically, by the passage of storms that export sea ice out of the region, enhance turbulent mixing in the ocean and may bring additional heat (Morales Maqueda et al., 2004; Cheon et al., 2015; Jena et al., 2019; Francis et al., 2019; Campbell et al., 2019). After the formation of the polynya by a particular event, the convection is self-sustained. The warmer, saltier waters at depth are strongly cooled when they reach the surface by direct exchanges with the atmosphere, become denser and sink again to great depths. This convection also provides a preconditioning for subsequent years as it maintains a low stability of the water column, explaining why open-ocean convection and polynya formation can be sustained over several years.

The great Weddell Sea polynya of the 1970s originated in the region close to a seamount called Maud Rise (at about $64^{\circ} \mathrm{S}, 3^{\circ} \mathrm{E}$ ). This region is considered to be particularly prone to polynya formation, and short-lived polynyas are often observed there (Comiso and Gordon, 1996; Morales Maqueda et al., 2004). The main reason for this is interactions between the topography and the large-scale circulation that lead to a shallowing of the mixed layer, upwelling of warmer deep water and the generation of mesoscale oceanic eddies, inducing an overall reduced stability of the water column (Carsey, 1980; Comiso and Gordon, 1987; Holland, 2001; Kurtakoti et al., 2018).

The direct contact between the ocean at a temperature close to its freezing point and the very cold air above in open-ocean polynyas in the winter has significant impacts on the atmosphere. The large turbulent fluxes induce an increase in the air temperature over the polynya area that can lead to a $20^{\circ}$ warming in winter compared with non-polynya years (Moore et al., 2002). The enhanced evaporation over the polynya induces a higher moisture content of the air, more clouds and more precipitation locally (Carsey, 1980; Moore et al., 2002; Weijer et al., 2017). The surface conditions may also cause a decrease in the sea level pressure over the polynya and, thus, influence the atmospheric circulation (Timmermann et al., 1999; Moore et al., 2002; Latif et al., 2013; Weijer et al., 2017; Kaufman et al., 2020). The local anomaly created over the polynya is transported downwind (e.g., Weijer et al., 2017), influencing the oceanic regions outside the polynya area as well as the Antarctic continent. However, the signal there is less strong than over the polynya region, and it is generally difficult to identify the effect of the polynya within the natural variability of the climate system (Carsey, 1980; Moore et al., 2002; Weijer et al., 2017).

Climate models have relatively large biases in their representation of vertical exchanges and deep-water formation in the Southern Ocean (Heuzé et al., 2013; Sallée et al., 2013). A few models display intermittent open-ocean convection that leads to the formation of polynyas covering a wide range of sizes and durations (Stössel and Kim, 2001; Martin et al., 2013; Zanowski et al., 2015; Weijer et al., 2017; Zhang et al., 2019; Kaufman et al., 2020). By contrast, widespread open-ocean convection occurs nearly every year in some models (Manabe et al., 1991; Goosse and Fichefet, 2001; Heuzé et al., 2013; Stössel et al., 2015), whereas other models have limited or no open-ocean convection.

Unfortunately, the short instrumental records do not provide precise estimations of the frequency and the overall role of polynya formation and deep convection in the climate system nor can they be used to determine which climate models represent polynya occurrence adequately. It has been speculated that open-ocean convection was more widespread in the past, with a reduction over the last decades that may have been caused by the large-scale freshening observed in the Southern Ocean (de Lavergne et al., 2014). Human-induced climate change will likely further reduce the probability of ocean convection in the future (de Lavergne et al., 2014; Heuzé et al., 2015; Kurtakoti et al., 2018). However, it is difficult to assess the magnitude of any recent change in polynya occurrence or their impact.

An option is then to study a time period that is longer than the one covered by instrumental observations and to rely on the signal stored in natural archives. Unfortunately, 


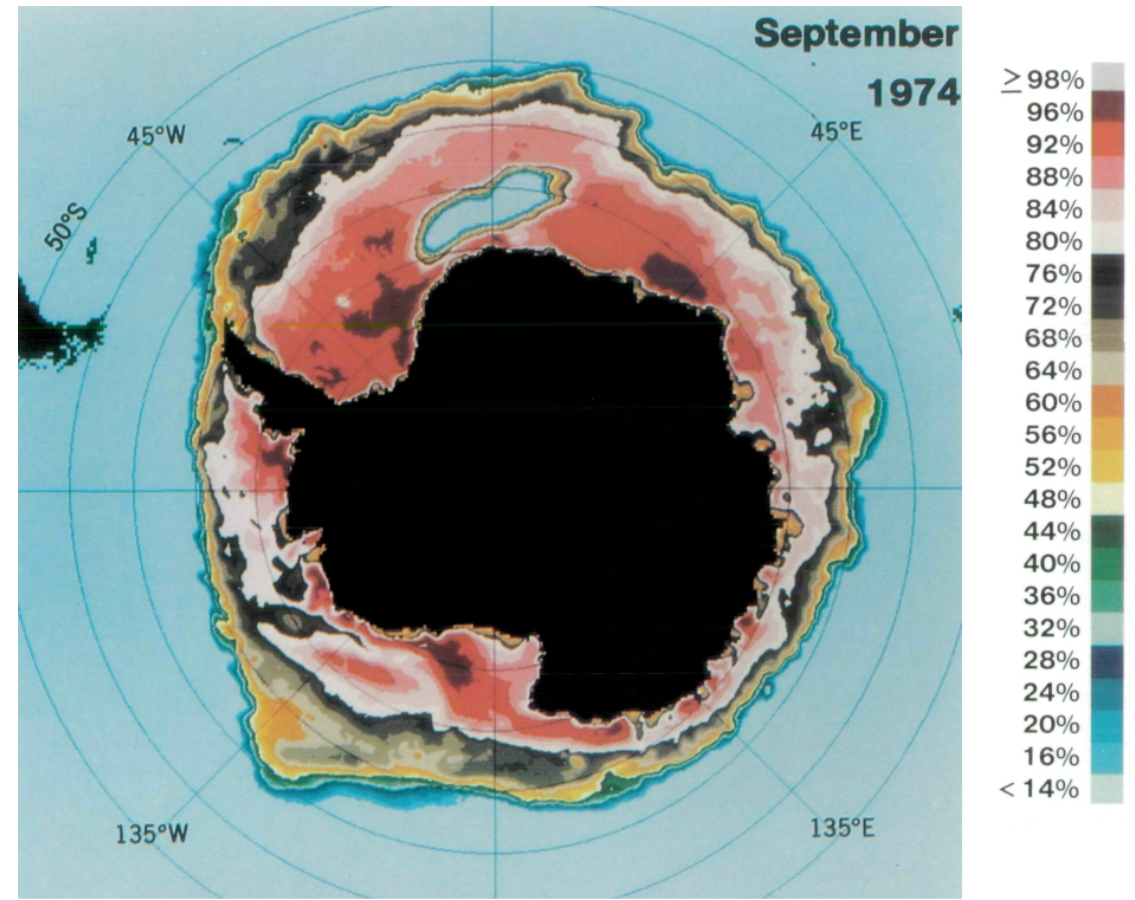

Figure 1. The Weddell Sea polynya in Austral winter, September 1974. Violet and red correspond to a high sea ice concentration, and light blue corresponds to open ocean. The great Weddell Sea polynya is visible across the Greenwich meridian. Figure from Zwally et al. (1983).

to our knowledge, no high-resolution ocean sediment core that might provide a direct record of polynya activity is available, and, to date, no reconstruction of polynya occurrence has been developed for the past centuries. This implies that the frequency of open-ocean polynya formation is basically unknown. However, polynyas also have an influence on the continent, and it might be possible to reconstruct their occurrence from a network of continental records. In that framework, ice core records are likely the best candidate, as they provide high-resolution, well-dated records of climate changes over the Antarctic continent.

Our goal here is to test if it is possible to reconstruct polynya activity using available ice core records, in particular the water isotopic composition $\left(\delta^{18} \mathrm{O}\right)$ and surface mass balance for which recent compilations have been developed (Stenni et al., 2017a; Thomas et al., 2017). The first step is to estimate, using modern observations and model results, where the signal is likely to be the clearest over the continent. This is done in Sect. 3. To leave an imprint in a natural archive, which generally has an annual resolution at best, the polynya must be large enough and stay open for a sufficiently long time. Thus, we focus on major events such as the great Weddell polynya observed in 1974, 1975 and 1976. In Sect. 4, we then determine how the ice core data can constrain the evolution of polynyas over the past centuries using a very simple statistical technique and data assimilation. The final section (Sect. 5) presents the conclusions of our analyses and discusses some perspectives for future developments.

\section{Data and methods}

\subsection{Observations}

To characterize the continental temperature changes occurring during the opening of the great Weddell Sea polynya in 1974, 1975 and 1976, we will first use direct observations from weather stations as well as a spatial reconstruction of temperatures based on these observations covering the 1958 2012 period (Turner et al., 2004; Nicolas and Bromwich, 2014).

Measuring precipitation directly in Antarctica is much more difficult than measuring temperature, and many weather station records do not include this variable routinely (Turner et al., 2004). Thus, we will rely on a recent synthesis of surface mass balance (SMB) from 79 ice cores (Thomas et al., 2017). The surface mass balance is defined as the net surface accumulation resulting from precipitation minus the removal from snow drift and sublimation, but it is mainly influenced by snowfalls over Antarctica (e.g., Lenaerts et al., 2019). The ice core data provide direct but point estimates at the core locations. Additional information on the spatial structure of the changes during polynya formation can be obtained from a reconstruction of the surface mass balance (Medley and Thomas, 2019) that combines ice core data and atmospheric reanalysis fields in order to cover the whole grounded Antarctic ice sheet over the past 200 years. This combination has the advantage of using the spatial covariance represented in the reanalysis without the potential 
troubles associated with the lower quality of the reanalyses before 1979 and the inhomogeneities due to the inclusion of additional satellite observations after that date (Marshall, 2003; Nicolas and Bromwich, 2014).

In addition to the characterization of the changes occurring in the 1970s, the SMB records will be one of the main sources for our reconstruction of polynya activity over the past centuries. The other data set is a synthesis of isotopic variations $\left(\delta^{18} \mathrm{O}\right)$ including 112 cores (Stenni et al., 2017a). SMB and $\delta^{18} \mathrm{O}$ are the two variables measured in the ice cores selected here, because they are used routinely to interpret past changes in precipitation and temperature over Antarctica. Furthermore, the syntheses available (Stenni et al., 2017a; Thomas et al., 2017) provide a reasonably good coverage over Antarctica, in particular in the South Atlantic sector where we expect the strongest signature of the great Weddell Sea polynya formation. Several model-data comparisons have also been carried out using those variables (e.g., Klein et al., 2019; Dalaiden et al., 2020; Cavitte et al., 2020), which provide a basis for the reconstructions using data assimilation proposed here.

Stenni et al. (2017a) and Thomas et al. (2017) selected only ice cores with a good time resolution and a low dating uncertainty. Therefore, the dating error is small for the cores included in these syntheses with a maximum of a few years over the past centuries. This is essential for polynya detection as a sequence of opening may only last a few years. Here, we will be even more strict and select only a subset of those data with annual resolution and the lowest age uncertainty, following the choice of Medley and Thomas (2019) (see Table 1).

From available records, it may be difficult to make the distinction between a year characterized by a few exceptional precipitation events, such as atmospheric rivers, that leave a large imprint on surface mass balance (e.g., Gorodetskaya et al., 2014; Turner et al., 2019) and the consequences of the opening of a polynya. As the focus here is on large openocean polynyas that are assumed to occur in a sequence of several years, a 3-year running mean is applied on the time series in the majority of our analyses. This provides a good balance between smoothing atmospheric events that may dominate at the interannual timescale while still being able to identify polynya sequences lasting a few years, such as the one between 1974 and 1976. We also remove the trend in the ice core records over the 1850-1992 period. This trend is likely largely due to processes unrelated to polynya formation (Medley et al., 2018; Medley and Thomas, 2019). A part of the trend could also be due to a recent shift in polynya activity (e.g., de Lavergne et al., 2014), although it is impossible to disentangle the various contributions at this stage. Thus, we choose to remove the trend to avoid misinterpretations. After detrending, we ensure that the mean of the ice core records before 1850 is the same as that after 1850 . This assumes a stationarity of the time series. Unfortunately, this procedure prevents us from comparing the frequency of open-ocean polynya formation during the 20th century with previous periods.

\subsection{Model results}

From a description of the observed temperature and precipitation changes in 1974, 1975 and 1976, it is impossible to disentangle the impact of polynya formation from the variability of the system that is not connected to the polynya itself. Thus, observations are complemented by the results of model simulations. The first simulation was performed with the ECHAM5-wiso atmospheric model (Steiger et al., 2017, 2018), which has a spatial resolution of $1.125^{\circ}$ and explicitly simulates the water isotopes. ECHAM5-wiso is driven by the observed changes in sea surface temperature and sea ice concentration from the Met Office Hadley Centre's sea ice and sea surface temperature data set over the period from 1871 to 2011 (Rayner et al., 2003 and updates). Thus, it provides a direct estimate of the model response in terms of temperature, SMB and $\delta^{18} \mathrm{O}$ over Antarctica to observed changes in ocean surface conditions in 1974, 1975 and 1976. Before 1973, no satellite imagery is included in the reconstruction of the sea ice cover in the Southern Ocean from Rayner et al. (2003 and updates), and sea ice concentration is derived from Antarctic atlas climatologies. Hence, the model boundary condition is more uncertain than for the more recent period, with a direct impact on the ECHAM5-wiso results. In our analysis, we compared the conditions in 1974, 1975 and 1976 to a model climatology established for the 1958-2000 period for consistency with the other data sources (the simulation results before 1958 are not used here). Nevertheless, our results in the region close to the Weddell Sea under the direct influence of the polynya are not sensitive to the reference period selected; for instance, results are very similar in this region if the reference period is shifted to 1979-2011, for which satellite data are available and the uncertainties on the estimates of the ice concentration are lower.

Several climate models display polynyas of various sizes and locations. Because of the triggering effect of Maud Rise, it is likely that if large polynyas occurred in the Weddell Sea before the 1970s, they were also located close to those observed in the 1970s. Nevertheless, assessing the realism of simulated polynyas is difficult, as we do not know if the sequence observed in the 1970s corresponds to the standard size of polynya we should expect in the current climate, if they were among the largest polynya observed during the past centuries or if much bigger polynya occurred earlier.

Here, two control simulations performed with the SPEAR (Seamless system for Prediction and EArth system Research) global climate model (Delworth et al., 2020), developed at the Geophysical Fluid Dynamics Laboratory, are chosen because they display intermittent polynya formation whose size and characteristics share many elements with observed changes in the Southern Ocean (Zhang et al., 2019; Delworth et al., 2020). They have constant forcing correspond- 
Table 1. Ice core records used in this study (based on Medley and Thomas, 2019, and Stenni et al., 2017a). The surface mass balance from the first six records are used in the reconstructions of the polynya activity. The other records (in italic) are only displayed in Figs. 2 and 3.

\begin{tabular}{llrrrrl}
\hline Number & Site name & $\begin{array}{r}\text { Longitude } \\
\left({ }^{\circ}\right)\end{array}$ & $\begin{array}{r}\text { Latitude } \\
\left({ }^{\circ}\right)\end{array}$ & $\begin{array}{r}\text { Altitude } \\
(\mathrm{m})\end{array}$ & Years CE & Reference \\
\hline 1 & Berkner Island (South) & -45.72 & -79.57 & 890 & $1000-1992$ & Mulvaney et al. (2002) \\
\hline 2 & B31-DML-07 & -3.43 & -75.58 & 2680 & $1000-1994$ & Graf et al. (2002) \\
\hline 3 & B32-DML-05 & -0.01 & -75.00 & 2892 & $1248-1996$ & $\begin{array}{l}\text { Graf et al. (2002), Sommer et al. (2000), } \\
\text { Oerter et al. (2000) }\end{array}$ \\
\hline 4 & B40 & 0.07 & -75.00 & 2892 & $1-2010$ & Medley et al. (2018) \\
\hline 5 & Fimbulisen S100 & 4.8 & -70.24 & 48 & $1737-1999$ & Kaczmarska et al. (2004) \\
\hline 6 & B33-DML-17 & 6.5 & -75.17 & 3160 & $1250-1997$ & Graf et al. (2002), Sommer et al. (2000), \\
\hline 7 & Derwael Ice Rise IC12 & 26.34 & -70.25 & 450 & $1744-2011$ & Phillipe et al. (2016) \\
\hline 8 & H72 & 41.08 & -69.2 & 1214 & $1832-1999$ & Nishio et al. (2002) \\
\hline 9 & IND 22B4 & 11.54 & -70.86 & 500 & $1533-1994$ & Laluraj et al. (2011) \\
\hline 11 & NUS 08-7 & 1.6 & -74.12 & 2673 & $1382-2008$ & Steig et al. (2013) \\
\hline 12 & NUS 07-1 & 7.94 & -73.72 & 3174 & $1706-2005$ & Steig et al. (2013) \\
\hline
\end{tabular}

ing to preindustrial conditions and are not constrained by any observations. Thus, they could not reproduce the conditions specifically observed in the 1970s, but they simulate a large number of polynya events, which allows for a robust attribution of the impact of modeled polynya on the Antarctic continent. Furthermore, these simulation results provide the model prior in the data assimilation, as explained below. Therefore, it is important to assess their characteristics compared to observations.

The two SPEAR simulations use the same ocean model, MOM6, with the SIS2 sea ice component (Adcroft et al., 2019), at a horizontal resolution of about $0.5^{\circ}$ in the Southern Ocean. The first simulation, referred to as SPEAR_LO hereafter, includes the AM4 atmospheric component (Zhao et al., 2018) at a resolution of about $100 \mathrm{~km}$. The second, SPEAR_AM2, uses AM2 (Anderson et al., 2004), an earlier version of the model at a resolution of about $200 \mathrm{~km}$ (see Zhang et al., 2020, for a longer description of the differences between the two simulations). For both simulations, we analyze the last 1000 years of the experiments here, corresponding to years $2000-3000$ in SPEAR_AM2 and years 3000-4000 in SPEAR_LO.

\subsection{Reconstruction methods}

For the reasons explained in Sect. 4, we have only selected the surface mass balance records for our reconstructions. The occurrence of polynyas over the past centuries is first estimated using a simple and direct method that will be described in the same section. Additionally, the history of past polynya formation is derived using data assimilation, which is a technique that has been applied recently to reconstruct climate fields, such as surface temperature and variables related to hydrology, over the past millennium (e.g., Goosse et al., 2012; Hakim et al., 2016; Franke et al., 2017; Steiger et al., 2018). Here, we apply so-called offline or non-cycling data assimilation as in many previous studies (e.g., Hakim et al., 2016; Franke et al., 2017; Steiger et al., 2018; Klein et al., 2019), meaning that it is based on an existing ensemble and no additional simulation is performed in contrast to online data assimilation.

The objective of data assimilation as implemented here is to combine model results and observations to reconstruct the state of the climate system; the timing of the occurrence of open-ocean polynya in the Weddell Sea can then be deduced from this reconstruction. The technique is based on a particle filter, following the implementation of Dubinkina and Goosse (2013) (see also Klein et al., 2019, and Dalaiden et al., 2020). An ensemble of simulated states is first obtained from annual means of all of the years of the control runs of SPEAR_AM2 or SPEAR_LO. This forms what is referred to as the prior distribution. For every year of the reconstruction, the likelihood of each of these simulated annual mean states is evaluated from the differences between the model results and observations. The goal is to obtain a quantitative estimate of the agreement between the observations for this specific year and each model state. From this likelihood, a weight is given to each model state. In other words, we evaluate the ability of each available model year to act as an analog for observed conditions during the selected year and give a higher 
weight to the best analogs. Formally, this provides the posterior distribution. More specifically, using those weights, we can compute a weighted mean of the model states that should be, by construction, close to the observations used as constraints in the evaluation of the likelihood (the selected surface mass balance observations here). This weighted mean can also be calculated for all of the other variables simulated by the model. Here, we focus on the changes in ocean convection, as this can be used to construct an index for polynya formation as explained in Sect. 3.

In our experiments with data assimilation, the records are averaged over $\sim 500 \times 500 \mathrm{~km}$ boxes, as coarse-resolution models are not expected to correctly represent smaller scales. These averages are shifted by a constant value and scaled to have the same mean and variance as the reconstruction of Medley and Thomas (2019) for the same boxes over the 1941-1990 period. The surface mass balance has a large spatial variability at all spatial scales (Thomas et al., 2017; Laepple et al., 2018; Cavitte et al., 2020), and this procedure provides values that are not too sensitive to the mean conditions at specific locations. Technically, in the present framework, this can be considered as part of the observation operator that allows the correspondence between the model space and observation space.

A key element in data assimilation is to obtain a reliable estimate of the observation error. As classically done, we consider that the errors are not correlated and that the observation error covariance matrix is diagonal. Because of the large spatial variability mentioned above, we also assume here that the representation error is much larger than the measurement error (Thomas et al., 2017; Laepple et al., 2018; Cavitte et al., 2020; Badgeley et al., 2020), and we only include the contribution of the former in our estimate of the error. The representation error is due, in particular, to the fact that the model is not able to simulate the small-scale processes that are included in the signal recorded in the archive (the so-called "error of representation due to unresolved scales and processes"; see, for instance, Janjić et al., 2018). The representation error is estimated by using a high-resolution (approximately $27 \mathrm{~km}$ ) simulation performed with the Royal Netherlands Meteorological Institute Regional Atmospheric Climate Model (RACMO) over the 1979-2016 period (van Wessem et al., 2018). It is obtained by calculating the standard deviation of the difference between the average of the annual mean surface mass balance time series using only the RACMO grid boxes where ice core records are available and the true average over the continental part of the $500 \times 500 \mathrm{~km}$ boxes. The mean of all of the simulated series over the 1976-2016 period is removed before the standard deviation is calculated in order to focus on the time variability within the boxes, not on the differences in mean snow accumulation. This standard deviation is then multiplied by a factor of 0.6 to take the smoothing associated with the 3-year running mean applied to the time series into account (see above). We prefer this method over the tech- nique of computing the standard deviation after applying a 3 -year running mean on the time series of simulated results due to the small number of samples in the RACMO simulation.

\section{Fingerprint of polynyas in the observations and models}

As discussed in Sect. 1, polynya formation is expected to have a larger impact in winter; however, as the resolution of the records is annual at best, we will focus on annual mean values here. The annual mean temperature in the reconstruction of Nicolas and Bromwich (2014) shows a large positive anomaly over the years from 1974 to 1976 in continental regions located close to the eastern Weddell Sea where the large polynyas appear in the 1970s. Specifically, higher temperatures are found between $50^{\circ} \mathrm{W}$ and the Greenwich meridian, with a maximum reaching more than $2{ }^{\circ} \mathrm{C}$ near the coast (Fig. 2a). As the number of weather stations is low in Antarctica, this positive temperature anomaly is mainly influenced by observations at the Halley station, which is located at $75.6^{\circ} \mathrm{S}, 26.6^{\circ} \mathrm{W}$ and is the weather station that is the closest to the great Weddell Sea polynya (Carsey, 1980). The other weather station with a long record in the region is Novolazarevskaya station $\left(70.8^{\circ} \mathrm{S} 11.8^{\circ} \mathrm{E}\right)$ which, by contrast, does not display particularly warm conditions at that time (Fig. 2b).

Halley station shows multidecadal variability with generally higher temperatures between 1970 and 1990 than in the following 2 decades. When applying a 3-year running mean to smooth interannual variability while keeping the signal associated with the observations of polynyas 3 years in a row, the maximum of the whole series is reached in 1976, i.e., during the polynya formation period. However, the annual mean temperature anomaly compared to the 1958-2000 period, with a value of $1.6^{\circ} \mathrm{C}$, does not appear exceptional or out of the normal range of variability for the region (the standard deviation of the annual mean temperature is $0.7^{\circ} \mathrm{C}$ ). Furthermore, when taking a 3-year period, the maximum at Halley station is not for the polynya years from 1974 to 1976 but is shifted by 1 year (1975-1977). This may be due to the drift of the polynya toward the west from 1974 to 1976 , moving closer to Halley station in the final years (Carsey, 1980; Zwally et al., 1983). Furthermore, we analyze annual mean temperatures here. The late freezing or the early melting of the sea ice in years preceding or following the polynya created large embayments but not strictly polynyas (Carsey, 1980; Zwally et al., 1983). Thus, the effect of the polynyas on annual mean temperatures can be extended in time, although, strictly speaking, no polynyas are formed in winter during those years.

Snow accumulation is also higher in the 1974-1976 period in the continental regions close to the polynya (Fig. 3a). The signal appears more spatially extensive in the SMB re- 


\section{Surface air temperature anomalies}
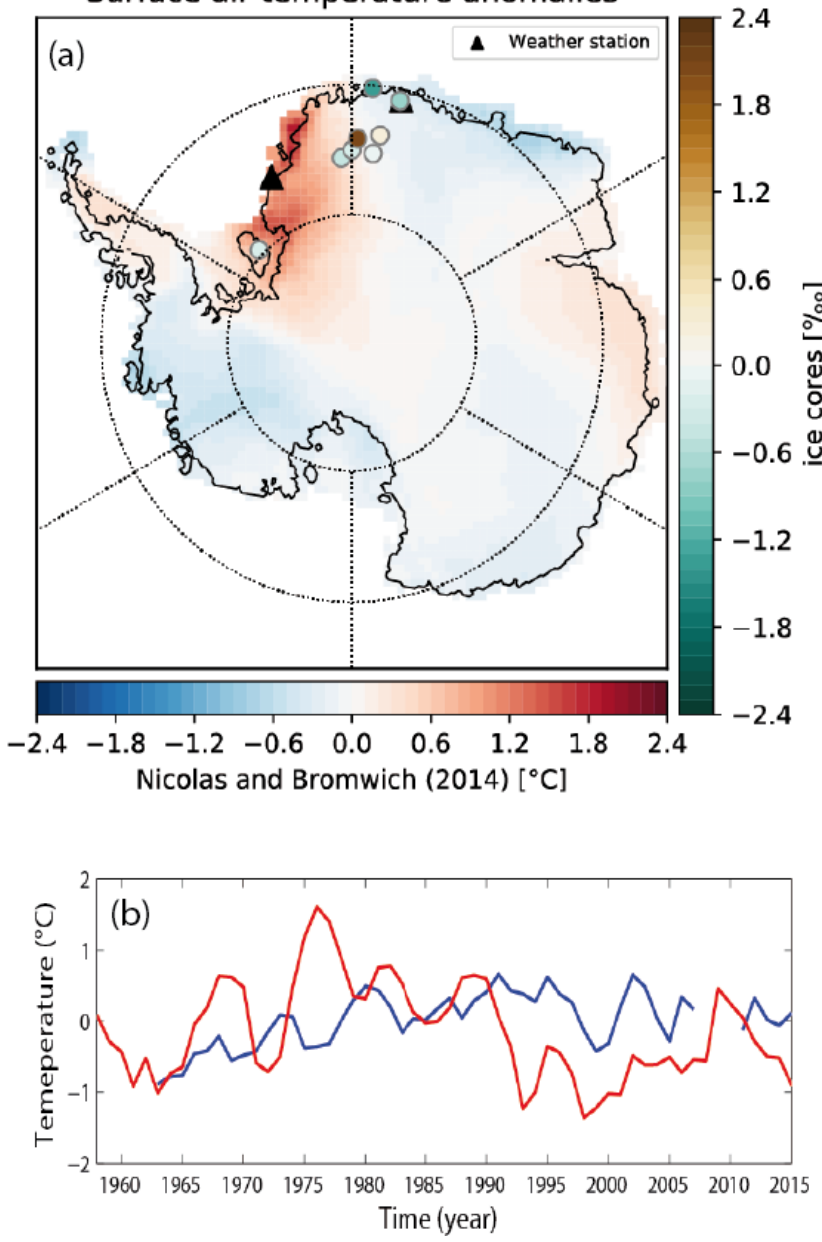

Figure 2. (a) Annual mean temperature anomaly $\left({ }^{\circ} \mathrm{C}\right)$ averaged over 1974-1976 compared with the 1958-2000 period in the Nicolas and Bromwich (2014) reconstruction. The dots correspond to the $\delta^{18} \mathrm{O}(\% \circ)$ anomalies for the same period in ice cores in the region of interest. (b) Annual mean temperature anomaly $\left({ }^{\circ} \mathrm{C}\right)$ at Halley (red) and Novolazarevskaya (blue) weather stations (highlighted in panel a). A 3-year running mean has been applied to the series.

construction of Medley and Thomas (2019) than for temperature in the Nicolas and Bromwich (2014) reconstruction, with positive values over nearly half of the continent. However, it is not clear if they are all related to the great Weddell Sea polynya formation.

The integrated SMB over the continental region close to the polynya, defined here as the domain between $50^{\circ} \mathrm{W}$ and $0^{\circ} \mathrm{E}$, north of $80^{\circ} \mathrm{S}$ (see the sector indicated in Fig. 3a), has a local maximum in 1975 after applying a 3-year running mean (Fig. 3b). This corresponds exactly to the 3 -year period with polynya formation, but the maximum does not particularly stand out in the time series and is, for instance, slightly lower than that in 1995 when no major polynya was observed. In this region, the snow accumulation averaged over the $1974-1976$ period is $12 \mathrm{Gtyr}^{-1}$ higher than the mean
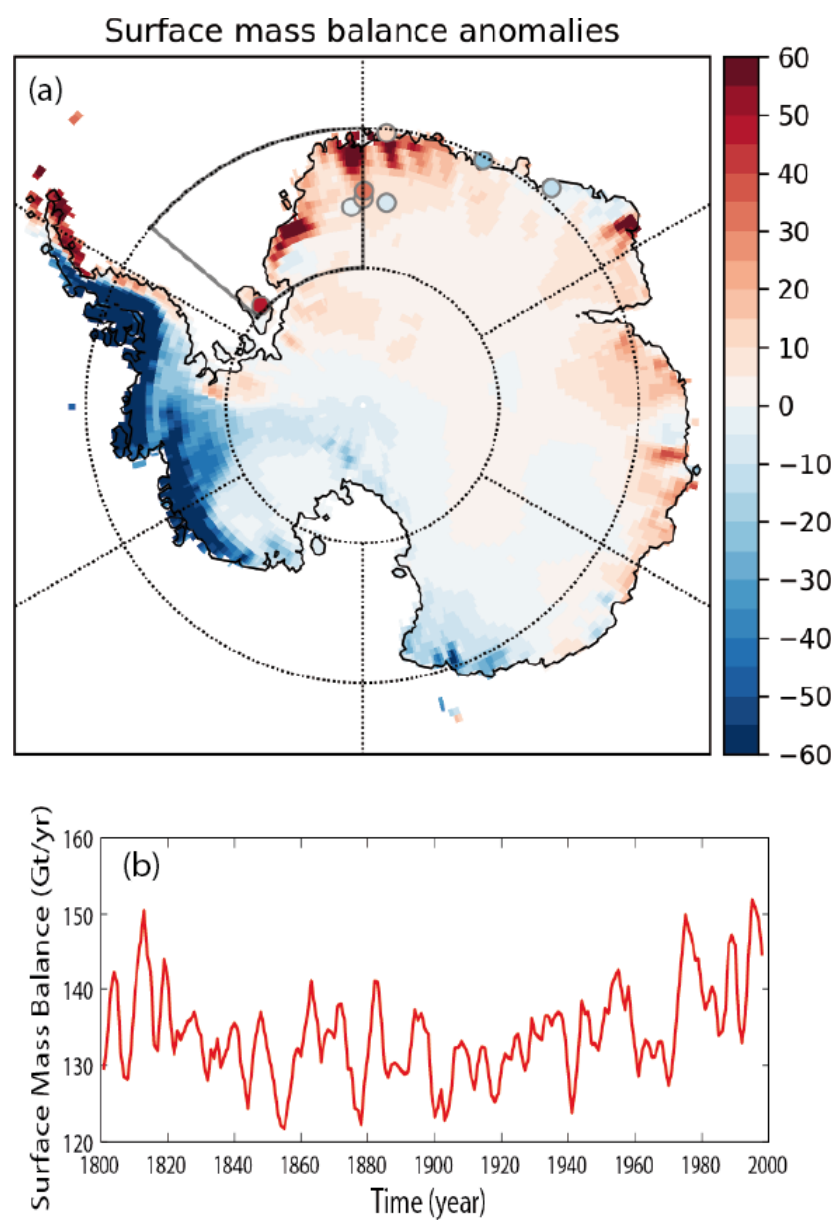

Figure 3. (a) Anomaly of SMB (mm w.e. $\mathrm{yr}^{-1}$ ) averaged over 1974-1976 compared with the 1958-2000 period in the Medley and Thomas (2019) reconstruction. The dots correspond to the estimates from the ice cores in Table 1. In the figure, the B40 core has been shifted northward by $0.6^{\circ}$ in order to avoid a overly large overlap with nearby cores. (b) SMB $\left(\mathrm{Gt} \mathrm{yr}^{-1}\right)$ integrated over the grounded ice sheet between $50^{\circ} \mathrm{W}$ and $0^{\circ} \mathrm{E}$, north of $80^{\circ} \mathrm{S}$ (box in panel a) in Medley and Thomas (2019) reconstruction. A 3-year running mean has been applied to the series.

over the 1958-2000 period. If a slightly larger domain covering $50^{\circ} \mathrm{W}-50^{\circ} \mathrm{E}$ is considered, a value of $24 \mathrm{Gt} \mathrm{yr}^{-1}$ is obtained and 1975 is the absolute maximum over the 19582000 period. These numbers can be compared to a standard deviation of the SMB in those regions of 7 and $15 \mathrm{Gt} \mathrm{yr}^{-1}$, respectively, and a standard deviation at the scale of Antarctica of $57 \mathrm{Gt} \mathrm{yr}^{-1}$ over the 1958-2000 period in the Medley and Thomas (2019) reconstruction after applying a 3-year running mean.

The temperature signal in the ECHAM5-wiso simulation driven by observed sea surface temperature and ice concentration is very strong in the polynya region, with a warming reaching $2.5^{\circ} \mathrm{C}$ averaged over the $1974-1976$ period (Fig. 4a). A weak warming is also seen over a relatively 
small coastal band between $50^{\circ} \mathrm{W}$ and $0^{\circ}$, with maximum values a bit lower than $1^{\circ} \mathrm{C}$ in a few coastal regions. These values on the continent are smaller than those observed at Halley station for the same time periods, suggesting that the observed anomalies cannot be fully attributed to the polynya formation, that the simulations underestimate the temperature changes over the continent due to the great Weddell Sea polynya formation or that a combination of the two occurs.

Precipitation in this simulation increases strongly over the polynya as well as over the continent between $50^{\circ} \mathrm{W}$ and $0^{\circ}$ (Fig. 4b). However, precipitation tends to decrease between $0^{\circ}$ and $50^{\circ}$ E. Compared with observations, the signal appears more contrasting and the increase is only clear over the continent west of the Greenwich meridian. At the daily timescale, the wind direction controls the location and amplitude of the temperature and precipitation signal related to polynya formation, as described in the model study of Weijer et al. (2017). An increase in precipitation over land is seen mainly when the winds comes from the north (in particular from the northeast; their Fig. 6) bringing the moist air originating in the polynya region, where evaporation is high, towards the continent. Close to the coast, the dominant easterly winds tend to push this moist air towards the west, explaining the larger signal found on the continent southwest of the polynya, as shown in Fig. 4. The net change in snow accumulation in the simulation averaged over the 1974-1976 period and integrated over the region from $50^{\circ} \mathrm{W}$ to $0^{\circ}$, south of $80^{\circ} \mathrm{S}$ is $+13 \mathrm{Gt} \mathrm{yr}^{-1}$ compared with the mean over the 1958 2000 period for the same region - a value surprisingly close to that in the reconstruction of Medley and Thomas (2019).

The $\delta^{18} \mathrm{O}$ of precipitation is often related to temperature, but the link can be weak and complex, in particular in coastal regions of Antarctica where the impact of polynyas is expected to be the largest (e.g., Masson-Delmotte et al., 2008; Sime et al., 2008; Holloway et al., 2016; Klein et al., 2019; Goursaud et al., 2019). This is even more problematic in the case of open-ocean polynya formation where large changes in the seasonality of precipitation are expected. Nevertheless, the pattern of annual mean $\delta^{18} \mathrm{O}$ of precipitation (Fig. 4c) associated with polynya formation is relatively similar to that for temperature (e.g., high positive values over the polynya but only low positive values over the continent except in a few regions close to the polynya). The ice cores record the signal in the precipitation accumulated over 1 year at least (e.g., Stenni et al., 2017a), and the $\delta^{18} \mathrm{O}$ of precipitation weighted by the amount of precipitation is a more adequate variable to compare to observed values. For this diagnostic (Fig. 4d), the signal becomes even weaker over the continent, with only a few coastal regions where the anomaly in annual mean $\delta^{18} \mathrm{O}$ reaches $0.5 \%$.

Consequently, the analyses of observations and model results indicate that, although the maximum of the surface response to polynya formation is expected over the ocean in winter, the polynya opening has likely induced a warming over the continent on average over the $1974-1976$ period, as well as an increase in snow precipitation and a small modification of the $\delta^{18} \mathrm{O}$ of precipitation. However, the signal is not strong enough to detect the direct effects of the polynya without ambiguity compared with other processes that can also lead to large interannual climate variations. Unfortunately, for a polynya opening over 3 years only, we are unable to use any statistical test of significance that would give us a stronger conclusion.

In order to obtain complementary information on polynya dynamics and quantitatively compare the observed changes in the 1970s with the results of the SPEAR model, an index of open-ocean convection and polynya activity is obtained in SPEAR_AM2 and SPEAR_LO control simulations by defining and calculating the annual mean mixed layer depth in the eastern Weddell Sea between $50^{\circ} \mathrm{W}$ and $50^{\circ} \mathrm{E}$, south of $60^{\circ} \mathrm{S}$. Open-ocean convection occurs only in winter, but the variability of the mixed layer depth in the annual mean is controlled by the winter values. Therefore, using the annual mean avoids making an arbitrary choice of which months to select for the average, as convection can take place over a long period. Figure 5 displays the regression of temperature and precipitation onto the abovementioned mixed layer depth index for the last 1000 years of the SPEAR_AM2 and SPEAR_LO simulations.

For the last 1000 years of the simulation, SPEAR_AM2 simulates recurring polynyas with centers around $20^{\circ} \mathrm{E}$ that induce a warming of up to $0.5^{\circ} \mathrm{C}$ per standard deviation of the mixed layer depth index over the continent close to the coast. Precipitation over the continent also increases in response to polynya formation, with a total increase in snow accumulation over the region from $50^{\circ} \mathrm{W}$ to $0^{\circ}$, north of $80^{\circ} \mathrm{S}$ of $17 \mathrm{Gt} \mathrm{yr}^{-1}$ per standard deviation of the mixed layer depth index $\left(30 \mathrm{Gt} \mathrm{yr}^{-1}\right.$ per standard deviation for the region from $50^{\circ} \mathrm{W}$ to $50^{\circ} \mathrm{E}$ ). This pattern is very similar to the one deduced from both the observations in the 1970s and the ECHAM5-wiso simulation.

In SPEAR_LO, the deep mixing and polynya formation in the Weddell Sea is concurrent with oceanic convection in the Ross Sea (Zhang et al., 2020). Consequently, the warming and precipitation signal is more widespread over the continent. Close to the Greenwich meridian, the warming of the coastal regions is of the order of $0.5^{\circ} \mathrm{C}$ per standard deviation of the index as in SPEAR_AM2 simulation. The changes in snow accumulation over the region from $50^{\circ} \mathrm{W}$ to $0^{\circ}$, north of $80^{\circ} \mathrm{S}$ is $9 \mathrm{Gt} \mathrm{yr}^{-1}$ per standard deviation of the index $\left(41 \mathrm{Gt} \mathrm{yr}^{-1}\right.$ per standard deviation for the region from $50^{\circ} \mathrm{W}$ to $50^{\circ} \mathrm{E}$ ). Additionally, large warming and precipitation changes are observed in the simulation in the continental regions close to the eastern Ross Sea and the Amundsen Sea.

\section{Reconstructing past polynya activity}

Standard methods applied to reconstructions covering the past millennium rely more or less directly on the correlation 

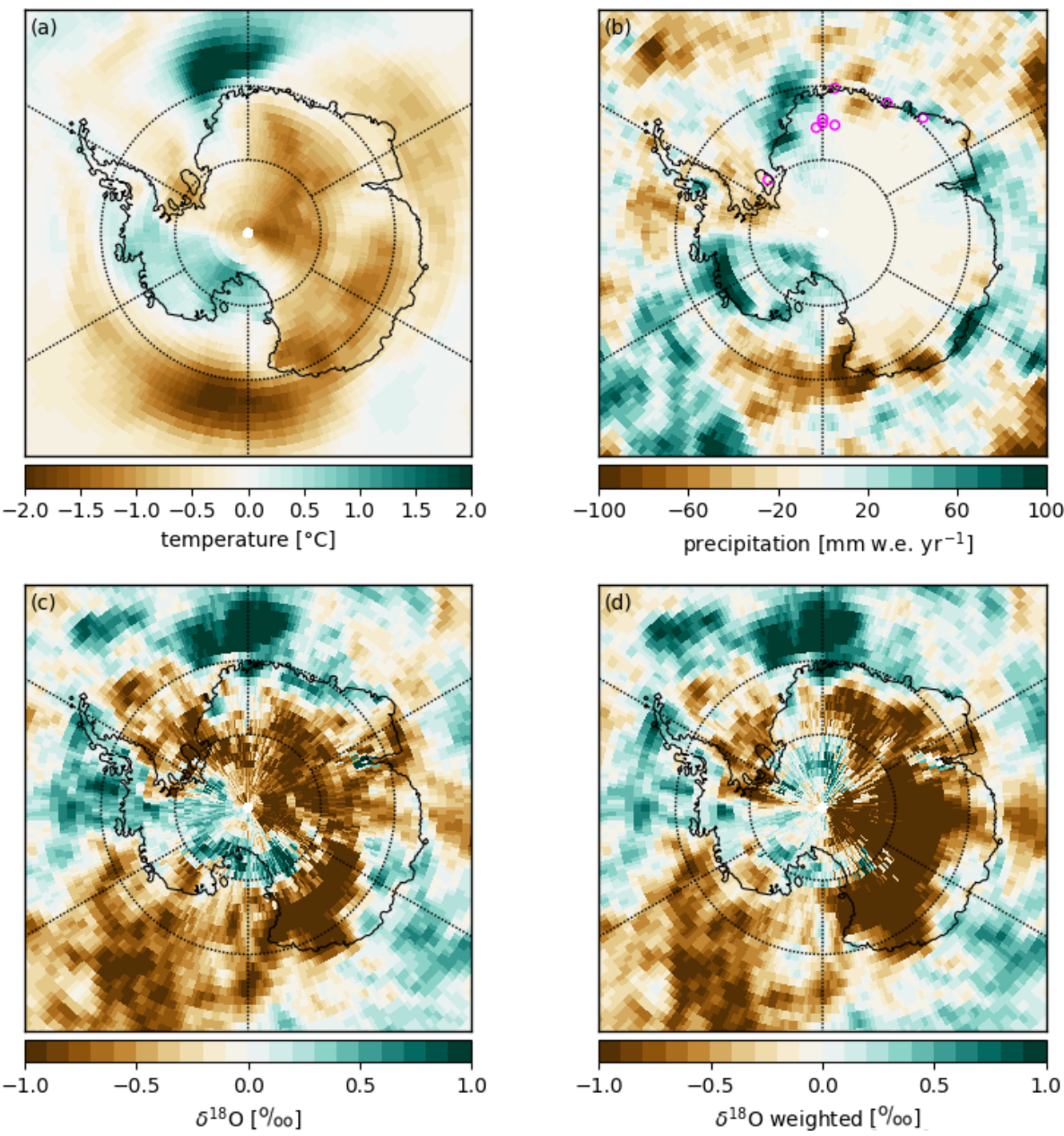

Figure 4. Anomaly of (a) annual mean temperature $\left({ }^{\circ} \mathrm{C}\right)$, (b) precipitation (mm w.e. $\left.\mathrm{yr}^{-1}\right)$, (c) mean $\delta^{18} \mathrm{O}$ of precipitation $(\%$ o) and (d) mean $\delta^{18} \mathrm{O}$ weighted by the precipitation amount (\%o) averaged over the 1974-1976 period compared with the 1958-2000 period in a simulation performed with ECHAM5-wiso. The circles in panel (b) correspond to the location of the ice cores in Table 1 with the B40 core shifted northward by $0.6^{\circ}$ in order to avoid an overly large overlap with nearby cores.

between the target (or predictand; here, the polynya activity) and some predictors (for instance, selected ice core records) over the instrumental period in order to calibrate a statistical model (e.g., Mann et al., 2008; Jones et al., 2009; Christiansen and Ljungqvist, 2017; Stenni et al., 2017a). This statistical model is then applied over the full period where the predictors are available to obtain a reconstruction of the target before the instrumental period. Here, this is not possible because the number of samples during the instrumental period is too small for any successful calibration. Thus, we have to use a slightly different approach.

We first apply a simple reconstruction method centered on the average of the records that are the most likely influenced by the formation of big polynyas in the Weddell Sea. The selection of these records is based on the information provided in Sect. 3.

A large warming has been measured at Halley weather station during the 1974-1976 period. However, the magnitude and the spatial extent of the temperature increase that can be directly attributed to polynya formation is ambiguous in observations and models. No direct long-term temperature record is available as input for our reconstructions. Highresolution temperature estimates before the instrumental period are often derived from the $\delta^{18} \mathrm{O}$ measured in ice cores, but the $\delta^{18}$ O signal over the 1974-1976 period in the simulation results is not very clear and relatively large values are restricted to a small continental region (Fig. 4d). Furthermore, when analyzing the available $\delta^{18} \mathrm{O}$ observations in the region close to the Weddell Sea, no well-defined pattern is identifiable (Fig. 2a). The record closest to Halley station (Berkner Island (South) ice core; see Table 1) even displays a decrease in $\delta^{18} \mathrm{O}$ over the time period from 1974 to 1976 , whereas, using a simplistic interpretation, we would have expected a higher value associated with the large warming observed in the region. Consequently, at this stage, $\delta^{18} \mathrm{O}$ records do not 

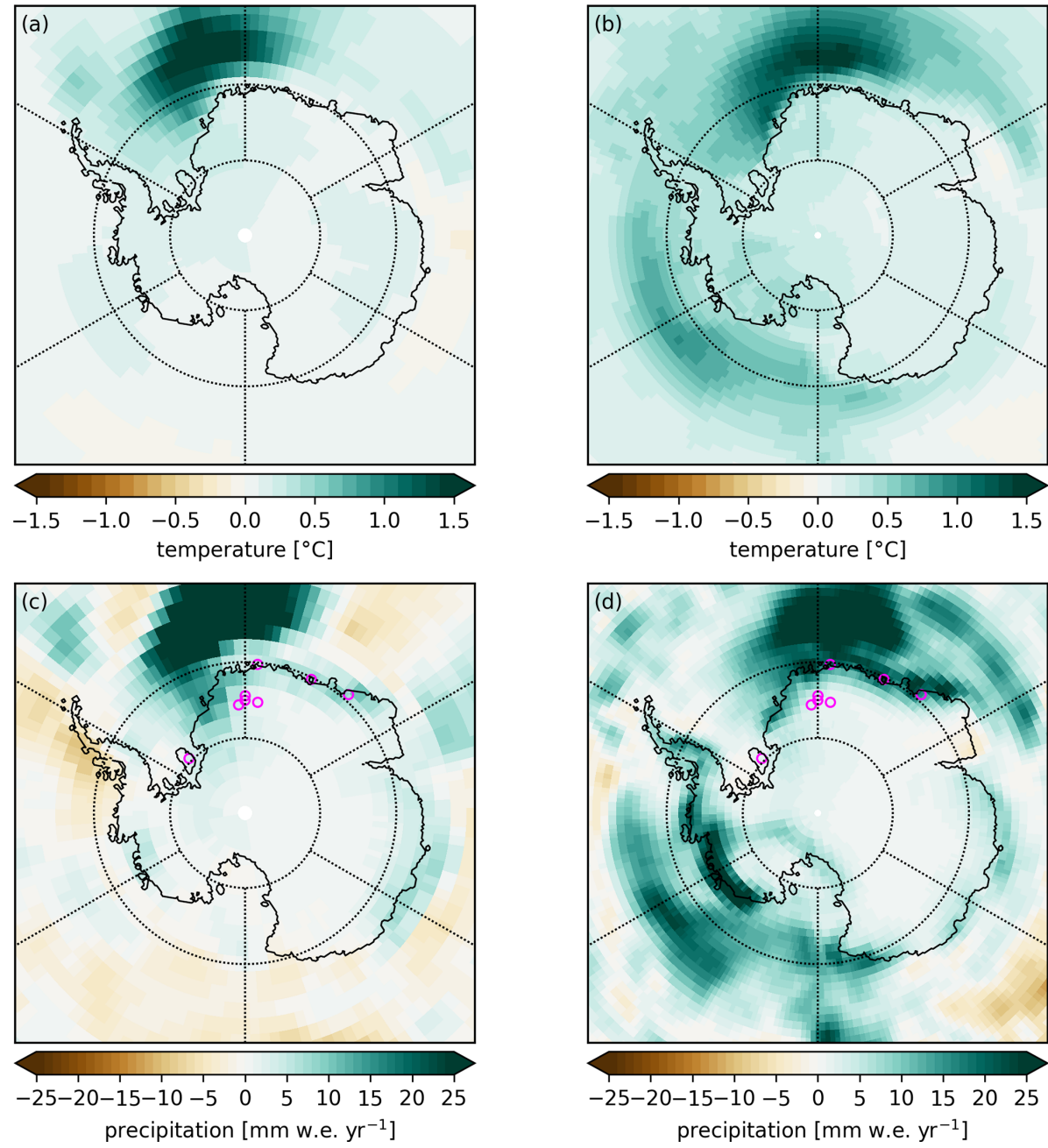

Figure 5. Regression of (a) annual mean temperature $\left({ }^{\circ} \mathrm{C}\right)$ and $(\mathbf{c})$ precipitation $\left(\mathrm{mm}\right.$ w.e. $\left.\mathrm{yr}^{-1}\right)$ scaled to correspond to 1 standard deviation change in the annual mean ocean mixed layer depth in the eastern Weddell Sea between $50^{\circ} \mathrm{W}$ and $50^{\circ} \mathrm{E}$, south of $60^{\circ} \mathrm{S}$ over the years from 2000 to 3000 of the SPEAR_AM2 simulation. (b,d) Same as panels (a) and (c) but for the years from 3000 to 4000 of the SPEAR_LO simulation. The circles in panels (c) and (d) correspond to the location of the ice cores in Table 1 with the B40 core shifted northward by $0.6^{\circ}$ in order to avoid an overly large overlap with nearby cores.

appear to be good candidates to reconstruct polynya activity with the simple methodology proposed here.

The reconstructions of the impact of the polynya formation on snow accumulation, based on ice cores, ECHAM5-wiso simulations for the 1970s and the control simulations with the SPEAR model, display contrasting changes over the continent. Nevertheless, they all present an increase in the snow accumulation of a similar magnitude between roughly $50^{\circ} \mathrm{W}$ and $0^{\circ}$. As open-ocean polynya formation has only been observed during a few years, it is impossible to determine which element in the observed snow accumulation for this period is a response to polynya formation and which is independent of the polynya. Simulations with SPEAR models provide a sufficiently large number of events to unambiguously identify the signal associated with polynya formation in the models, but this signal is influenced by model characteristics and biases. Nevertheless, the different sources of information are complementary, and it seems reasonable to focus on the characteristics common to all those sources, i.e., the higher snow accumulation between $50^{\circ} \mathrm{W}$ and $0^{\circ}$. This does not imply that a response to polynya formation can only be seen in this sector, but we can likely identify the most robust signal there. Furthermore, this higher snow accumulation has a clear and simple physical interpretation, as stronger evaporation in the polynya region is expected to lead to more precipitation downwind (Weijer et al., 2017).

Consequently, we propose basing our reconstructions on surface mass balance records alone. We focus on ice core records that are at least 150 years long in order to avoid too many changes in the number of records over the period of analysis (Table 1). If we consider the broader region between the Antarctic Peninsula (which is clearly outside the 
domain of direct influence of the great Weddell Sea polynya in our results) and $50^{\circ} \mathrm{E}$, eight surface mass balance fit our criteria in the data selected by Medley and Thomas (2019) (Fig. 3a). Two (Derwael Ice Rise IC12 at $26.34^{\circ} \mathrm{E}$ and $\mathrm{H} 72$ at $41.08^{\circ} \mathrm{E}$ ) are located in regions where the polynya opening may induce a response, but there is no consensus between the different estimates provided in Sect. 3. Thus, we do not keep them here. All of the others are located at the margin of the region where the most robust changes have been identified (see Figs. 3a, 4b and 5c, d). Therefore, we suggest focusing on these six records: Berkner Island $\left(45.72^{\circ} \mathrm{W}\right), \mathrm{B} 31-$ DML-07 $\left(3.34^{\circ} \mathrm{W}\right), \mathrm{B} 32-\mathrm{DML}-05\left(0.01^{\circ} \mathrm{W}\right), \mathrm{B} 40\left(0.07^{\circ} \mathrm{E}\right)$, Fimbulisen S100 $\left(4.8^{\circ} \mathrm{E}\right)$ and B33-DML-17 $\left(6.5^{\circ} \mathrm{E}\right)$. The signal over the 1974-1976 period from those cores is not homogeneous (Fig. 3a), but this could be related to the influence of local processes and post-depositional alterations in the records that may lead to relatively large differences even between nearby sites (Thomas et al., 2017; Laepple et al., 2018; Cavitte et al., 2020). Nevertheless, four of these six cores in the region have values in the 1974-1976 period that are higher than the mean over the 1958-2000 period (Fig. 3a), which is, of course, consistent with the spatial reconstruction of Medley and Thomas (2019) based on these records. As discussed in Sect. 2, all of the time series are detrended over the 1850-1992 period, and a 3-year running mean is applied prior to our analyses.

As no direct calibration of polynya activity with instrumental observations is possible, we first standardize all of the records by removing their mean and dividing by their standard deviation over the 1941-1990 period. We then perform the average of all these standardized records to obtain a qualitative index of polynya occurrence. This simple average has a physical justification: the common signal associated with polynya formation should be positive in all of the records, as polynya opening leads to more precipitation throughout the region of interest. The index is then scaled to have a value of 1 in 1975 for an easy comparison with the observed polynya in the years from 1974 to 1976 . The methodology could be considered as the equivalent of the classical composite plus scale approach but with a slightly different final step compared with previous studies that performed the scaling to fit with the observed variance of the reconstructed variable (e.g., Mann et al., 2008; Jones et al., 2009; Christiansen and Ljungqvist, 2017; Stenni et al., 2017a).

The same records are used in the reconstructions with data assimilation. In theory, data assimilation should be able to handle observations outside of the region where the signal is the strongest. However, extracting the information on polynya activity potentially included in these records requires that the model adequately simulates the covariance between the regions where the polynya forms and the ones where these records are available. As it is difficult to evaluate the model performance on this aspect, we have decided to focus on the six ice core records that are the most directly and strongly influenced by the polynya opening, as for the statistical method. As in Sect. 3, the index of polynya activity is computed from the annual mean mixed layer depth in the eastern Weddell Sea between $50^{\circ} \mathrm{W}$ and $50^{\circ} \mathrm{E}$. The index is scaled to have a value of 1 in 1975 , and the average over the 1941-1990 period has been removed to be consistent with the simple statistical reconstruction.

Because of the small number of records and the difficulty involved with performing an independent validation, a formal investigation of the uncertainties of our reconstructions is outside the scope of this study. Nevertheless, the robustness of our results can be estimated by comparing the indices obtained in the three methods: the statistical reconstruction and the two reconstructions with data assimilation using SPEAR_AM2 and SPEAR_LO simulations as priors, respectively (Fig. 6a). The two SPEAR simulations, which each display a polynya opening in a slightly different location in the Weddell Sea and an impact of these polynyas on snow accumulation over land characterized by a different pattern (Fig. 5), provide a rough range of the uncertainties associated with the simulation selected for the data assimilation. The sensitivity of the reconstruction to the selection of the records is also estimated by performing, for each method, alternative reconstructions based on all of the combinations of five out of the six ice core records (i.e., we excluded each record one by one). The uncertainty for each method is then obtained from the standard deviation of the seven reconstructions (the standard reconstruction including the six records and the six reconstructions with five records) (Fig. 6b, c, d).

The three reconstructions based on the three methods display significant differences during some periods, such as the 1950s, (Fig. 6a) and the choice of the records has a large impact (Fig. 6b, c, d). This illustrates the large uncertainties still present at this stage in our estimates of past changes in open-ocean polynya formation. Nevertheless, for the last 150 years, the reconstructions generally agree on the timing of the largest peaks, likely corresponding to polynya formation. In particular, all of the times series show a maximum in 1975, corresponding well to the 1974-1976 period with the 3-year running mean applied. This implies that we are able to robustly reproduce the opening of the great Weddell Sea polynya. Smaller peaks are also observed in some reconstructions (for instance in 1983 for the statistical reconstruction; index of 0.65 ), although these years are not considered as particularly prone to the formation of smaller polynyas (Campbell et al., 2019). Thus, the index seems able to identify the known period with large open-ocean polynyas; however, it may have trouble discriminating polynyas clearly from years with high snow accumulation in the sector, which may simply be caused by specific atmospheric conditions. The persistence of the polynyas over a few years helps to reduce the noise due to random atmospheric processes, but this is likely not enough. It is reasonable to consider that large open-ocean polynyas should systematically lead to a widespread anomaly in the surface mass balance in the continental region that is downwind from the polynya and, thus, 

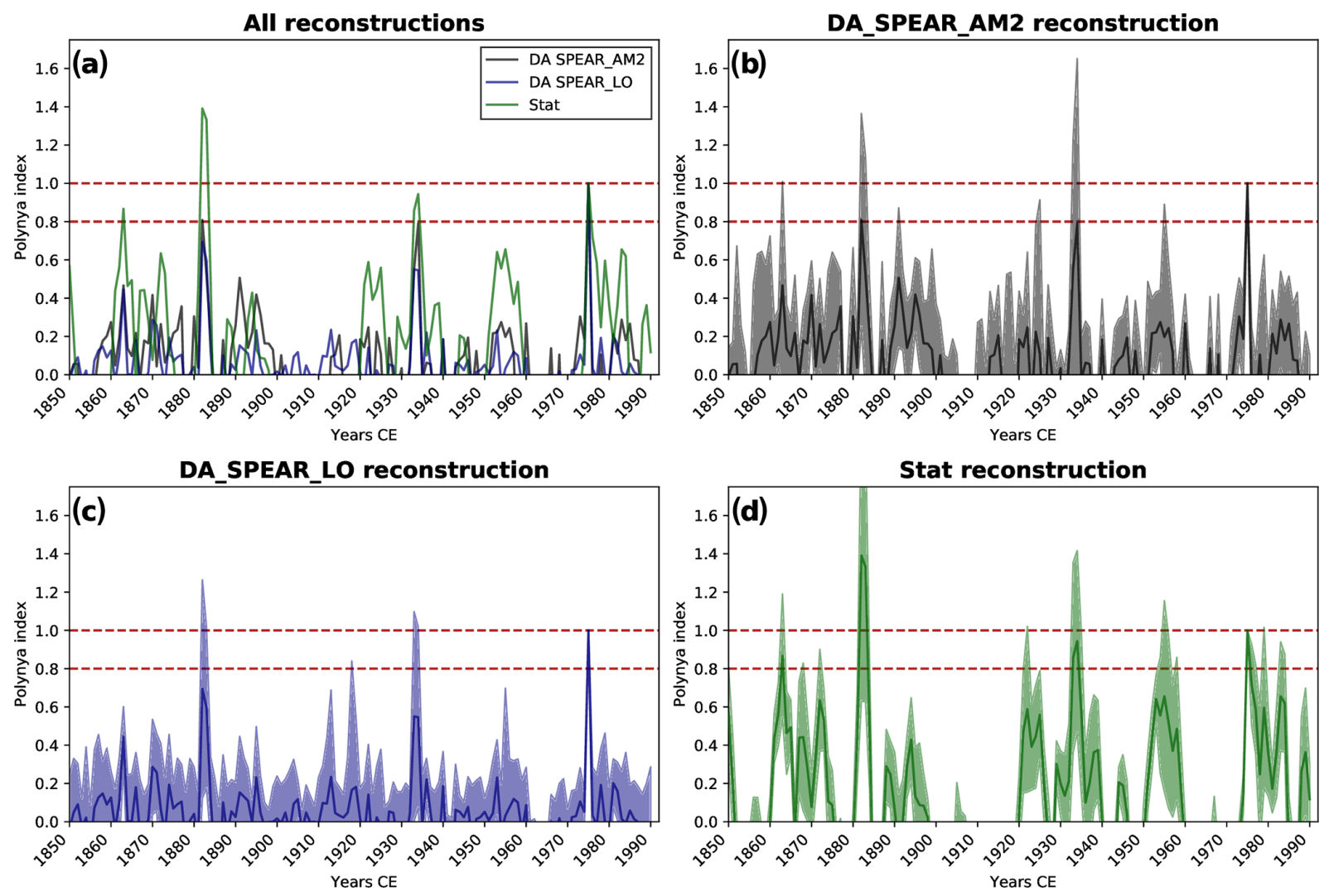

Figure 6. (a) Index of polynya activity for the years from 1850 to 1990 based on six surface mass balance records using data assimilation with SPEAR_AM2 (DA SPEAR_AM2 black), data assimilation with SPEAR_LO (DA SPEAR_LO, blue) and a simple average of the standardized time series (Stat, green). Index of polynya activity with the uncertainties estimated from the standard deviation of the seven reconstructions using six and all of the combinations of five different records for the reconstruction using (b) data assimilation with SPEAR_AM2, (c) data assimilation with SPEAR_LO and (d) a simple average of the standardized time series.

a high value of the index. By contrast, high snow accumulation is not necessarily caused by a polynya. In this framework, we can hypothesize that the index provides more "false positives" for polynya events than events that we completely miss.

Over the $1850-1990$ period, a local maximum is found in the three reconstructions in 1882, with a value larger than in 1975 for the statistical reconstruction. Relatively high values of the index are also found in 1934 in the three reconstructions as well as some other peaks in individual reconstructions. Gordon (1982) hypothesized that a polynya occurred just before an oceanic cruise performed in 1962. The years before those observations are characterized by a prolonged period with a relatively high index in the statistical reconstruction but no value above 0.7 in any of our reconstructions. Such values may correspond to changes in snow accumulation due to polynyas smaller than the one observed in 1975 , but this is impossible for us to determine if the explanation is valid from the available records. Additionally, from an analysis of early satellite imagery, Meier et al. (2013) hypothesized that a polynya formed in the Weddell Sea in 1964, although it is difficult to make the distinction between polynya opening and the presence of leads and clouds in the region based on the few available satellite images. The year 1964 is characterized by a low value of the index in all of our reconstructions. This does not at all rule out the formation of a short-lived event in 1964, but it suggests that no equivalent to the polynya formation observed in 1974-1976 occurred during this period.

For the preindustrial period, high values of the index are found regularly in nearly every century (Fig. 7). To be more quantitative, two threshold values for the index have been applied to detect polynya formation in Figs. 8 and 9. The value of 1 corresponds to events that have a similar imprint to the great Weddell polynya, whereas events with a smaller impact over the continent can still be detected with a value of 0.8 . In each of our reconstructions, a year with an index higher than this value of 0.8 should still correspond to large events, but the risk that a year with an index higher than 0.8 does not correspond to an open-ocean polynyas is higher (the false positives mentioned above) than for a threshold of 1 .

The open-ocean polynyas appear mainly as isolated events lasting only a few years, as observed in the 1970s. In addition to the isolated events, more persistent sequences (al- 

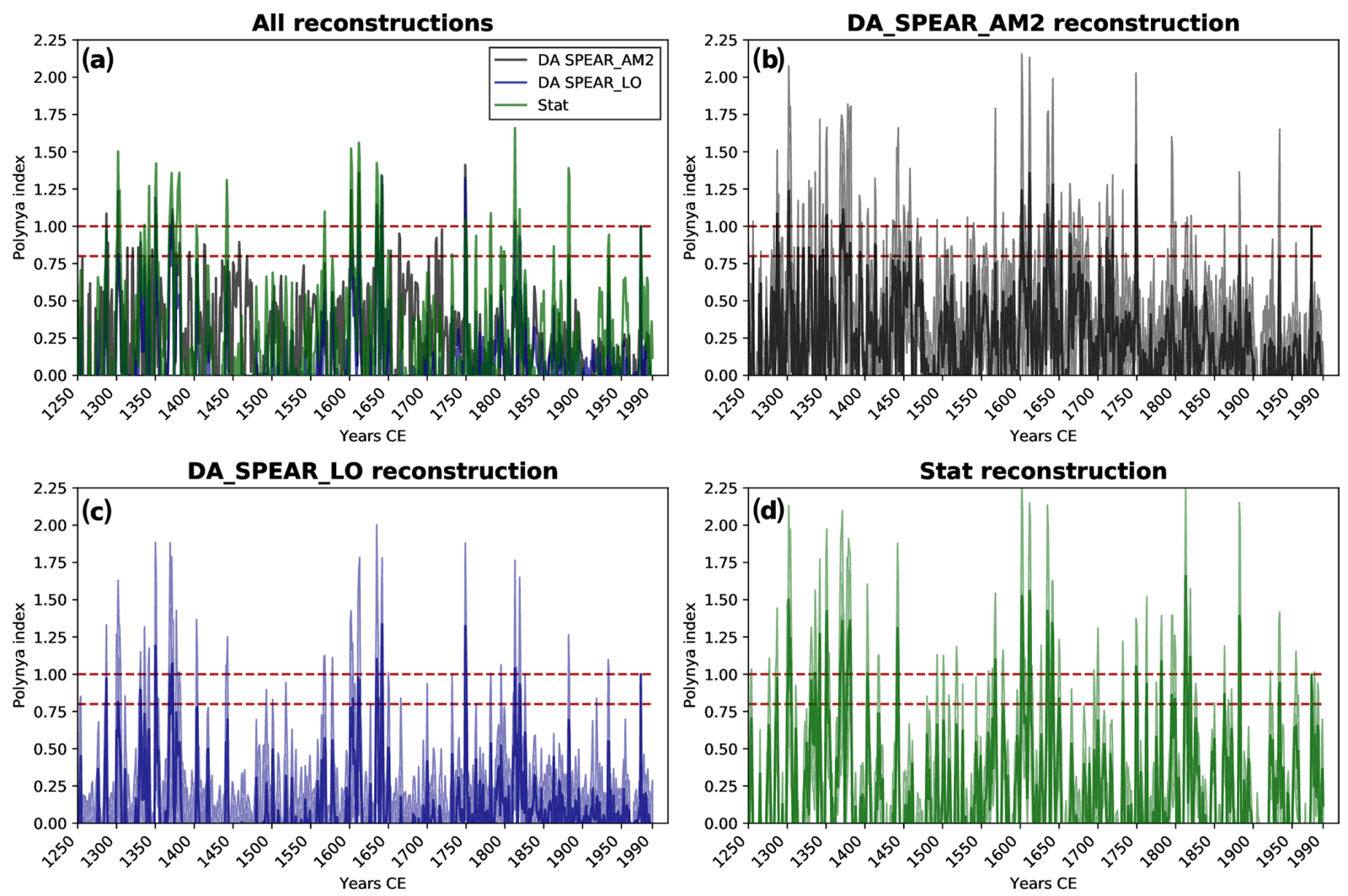

Figure 7. Same as Fig. 6 but for the years from 1250 to 1990.

though not continuous) are also reconstructed in particular over the 1350-1400 and 1600-1650 periods (Figs. 8, 9). By contrast, no polynyas are reconstructed during some other periods, such as the years from 1500 to 1550 , in all of the reconstructions and for both thresholds. This may be the signature of centennial-scale variability in polynya activity. Nevertheless, as we go back in time, the absence of events could simply be due to the dating uncertainties. A shift of only a few years between the records can lead to an event being attributed to different years in the different time series and, thus, to a muted value of the index when they are averaged. Low-frequency variations in the surface mass balance in the sector, due to processes independent of polynya formation, could also modify the background state over which the polynya signal is imprinted. A higher mean snow accumulation would then lead to a higher chance to pass the threshold of 0.8 or 1, whereas a lower mean snow accumulation would imply that only big polynyas would be detected. Finally, because of the detrending applied to the time series, we cannot compare the polynya activity over the past century with earlier periods.

\section{Discussion and conclusions}

Large and persistent open-ocean polynyas have a major impact on the ocean surface at high latitudes, on ocean dy- namics and on the deep-ocean properties, as highlighted in many studies. Their imprint on the Antarctic continent has been much less investigated. Because of the small number of events, precisely disentangling the signal at the ice sheet surface that is from an open-ocean polynya from other elements of the climate variability is impossible using instrumental data alone. Nevertheless, instrumental data and surface mass balance reconstructions suggest a clear impact of the great Weddell Sea polynya in the 1974-1976 period on the continent, at least in the sector between roughly $50^{\circ} \mathrm{W}$ and $0^{\circ} \mathrm{E}$. A comparison of the observed changes with the results of an atmospheric model driven by observed sea surface temperature and sea ice concentration suggests an annual mean warming of less than $1^{\circ}$ in coastal regions and an additional snow accumulation averaged over the sector of about $10 \mathrm{Gt} \mathrm{yr}^{-1}$ during polynya formation compared with average conditions.

Because of this impact of the open-ocean polynyas on the Antarctic ice sheet, it is tempting to use ice core records to reconstruct the occurrence of polynyas before the instrumental period. Surface mass balance records are the best candidates for an initial reconstruction because of their availability in the region close to the Weddell Sea. Furthermore, from robust physical arguments, polynya formation should be associated with an increase in snow accumulation in the sector downwind of the polynya. The signal is present in temperature as 

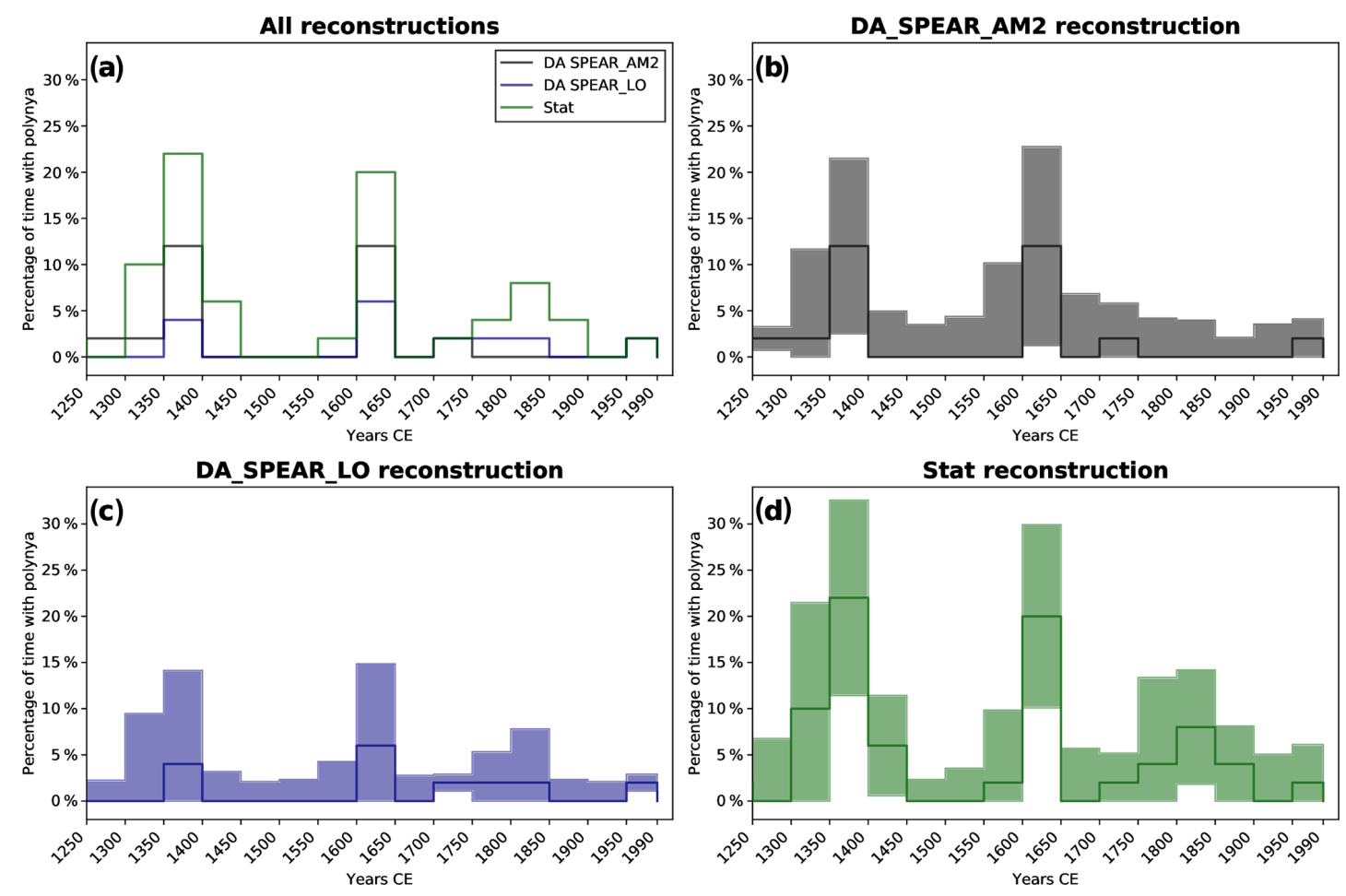

Figure 8. (a) Percentage of the years with the index of polynya activity higher than 1 per 50 -year time interval in the reconstructions using data assimilation with SPEAR_AM2 (DA SPEAR_AM2 black), data assimilation with SPEAR_LO (DA SPEAR_LO, blue) and a simple average of standardized time series (Stat, green). Percentage of the years with the index of polynya activity higher than 1 with the uncertainties estimated from the standard deviation of the seven reconstructions using six and all of the combinations of five different records for the reconstruction using (b) data assimilation with SPEAR_AM2, (c) data assimilation with SPEAR_LO and (d) a simple average of standardized time series.

well; however, it is weak for the isotopic composition of the snow, which is often considered as a proxy for temperature but whose interpretation is particularly complex here because of potential changes in the seasonality of precipitation due to open-ocean polynya formation.

Thus, we have reconstructed an index of polynya activity based on the surface mass balance records, using a simple average of the standardized series available in the sector from $50^{\circ} \mathrm{W}$ to $5^{\circ} \mathrm{E}$ as well as data assimilation constrained by those records over the 1250-1990 period. This reconstruction remains qualitative at present, and the uncertainties are still large. The surface mass balance changes caused by polynya formation are not exceptional enough to distinguish the origin of a large value without ambiguity. Furthermore, low-frequency variations in surface mass balance not related to polynya activity and dating uncertainties in the records, which could potentially have a very large impact for events lasting at most a few years, also complicate the detection of polynyas.

Additional information is necessary to identify the years with a high value of our index of polynya activity but that actually do not correspond to a polynya. First, additional surface mass balance records would allow for a reduction in the uncertainties and for the more clear extraction of the signal coming from the polynya, in particular if they are obtained in low-elevation regions in the sector from $10^{\circ}$ to $30^{\circ} \mathrm{W}$ (see, for instance, Goel et al., 2020, for potential drilling locations), and where all models selected here simulate the largest response to the formation of open-ocean polynya in the Weddell Sea. Furthermore, several proxies based on the chemical composition of Antarctic ice cores have been related to changes in sea ice concentrations (e.g., Abram et al., 2013; de Vernal et al., 2013; Thomas et al., 2019). For open-ocean polynya, sea salt aerosols provide interesting perspectives, as their source at the surface of polar oceans strongly depends on the presence of sea ice (e.g., Levine et al., 2014; Rhodes et al., 2018). Thus, the formation of an open-ocean polynya in winter should have a large impact on the sea salt input to the atmosphere in the Weddell Sea. This signal could then be transported to the continent by the winds and recorded in ice cores. Although biological activity in the polynya itself in winter may be limited, the formation of open-ocean polynyas can have an impact on the vertical structure of the water column, on light availability, on nutrient input to the surface layer and, in turn, on biological production later in the season (e.g., von Berg et al., 2020). This might also be recorded in ice cores (e.g., in their methanesulfonic acid content). These proxies have 

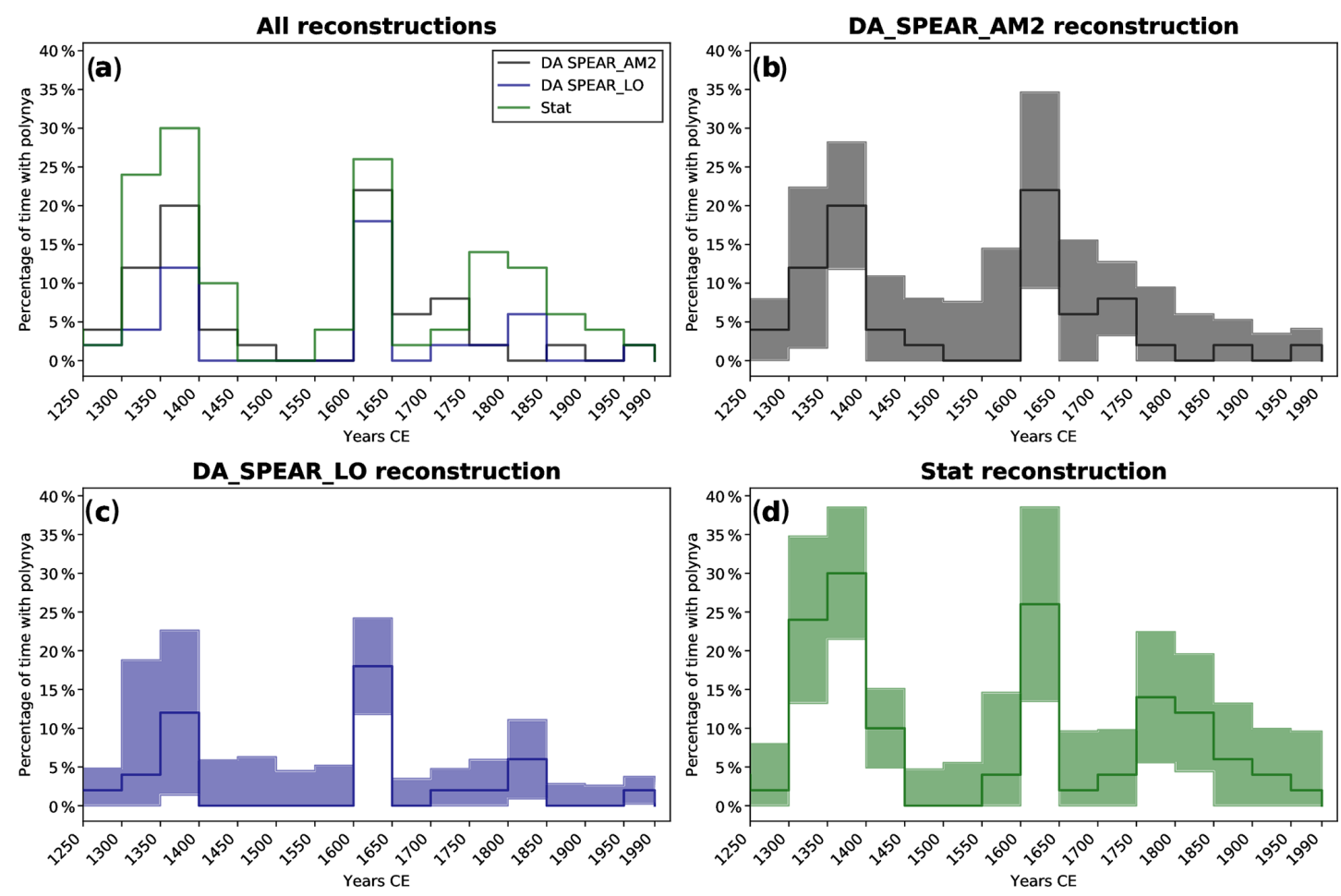

Figure 9. (a) Percentage of the years with the index of polynya activity higher than 0.8 per 50 -year time interval in the reconstructions using data assimilation with SPEAR_AM2 (DA SPEAR_AM2 black), data assimilation with SPEAR_LO (DA SPEAR_LO, blue) and a simple average of standardized time series (Stat, green). Percentage of the years with the index of polynya activity higher than 0.8 with the uncertainties estimated from the standard deviation of the seven reconstructions using six and all of the combinations of five different records for the reconstruction using (b) data assimilation with SPEAR_AM2, (c) data assimilation with SPEAR_LO and (d) a simple average of standardized time series.

been used to reconstruct coastal polynyas (e.g., Rhodes et al., 2009; Criscitiello et al., 2013; Mezgec et al., 2017). The specific impact of a large open-ocean polynya on these paleoclimate records is not well known, but some of these records likely have a signal related to open-ocean polynya formation that is large enough to place additional constraints on the reconstructions and reduce our uncertainties. Finally, if a high-resolution ocean sediment core could be collected at a location sensitive to open-ocean polynya formation in the Weddell Sea, it would provide complementary information that could be combined with the ice core records to refine the reconstructions, in particular to constrain the low-frequency variations in polynya activity.

In addition to those observations close to the region of polynya formation, another constraint on our reconstructions could come from a comparison to estimates of past largescale changes that are expected to favor open-ocean polynya formation or that would be a consequence of their occurrence. In particular, changes in surface winds influence the horizontal oceanic circulation, potentially inducing the upwelling of deep waters and, thus, a salt input in the surface layers, creating conditions more prone to deep convection (Cheon et al., 2015; Campbell et al., 2019; Kaufman et al., 2020). In this framework, it has been argued that a per- sistent negative phase of the Southern Annular Mode (which is the main mode of atmospheric variability in the Southern Hemisphere extra-tropics) in the preceding decade could have created favorable conditions for the formation of the Weddell polynya in the 1970s (Gordon et al., 2007; Kaufman et al., 2020). Reconstructions of the SAM over the past millennia (Abram et al., 2014; Dätwyler et al., 2018) indicate generally low values between 1350 and 1700 . This could be consistent with the high occurrence of polynya formation reconstructed from some periods such as $1350-1400$ and 1600-1650, but the uncertainties are too large to be able to reach strong conclusions on the agreement with our reconstructions.

The great Weddell Sea polynya of the 1970s had a large impact on the ocean state. The heat loss has been estimated to be of the order of $0.4 \times 10^{21} \mathrm{~J} \mathrm{yr}^{-1}$ (Gordon, 1982). This corresponds to $4 \%$ of the heat stored in the ocean in response to human-induced perturbations in recent years (about $1 \times 10^{22} \mathrm{~J} \mathrm{yr}^{-1}$; Lyman and Johnson, 2014; Resplandy et al., 2019). Furthermore, the deep convection occurring in polynyas can lead to the formation of Antarctic Bottom Water $(\mathrm{AABW})$. $\mathrm{AABW}$ is a key water mass, present over the majority of the ocean floor, and occupies more than $30 \%$ of the global ocean volume (Mantyla and Reid, 1983; Johnson, 
2008). It has its main origin at the margin of the Antarctic continent where cold and salty waters, formed on the Antarctic continental shelves because of brine rejection during sea ice formation, sink to great depths (Foster and Carmack, 1976; Purkey et al., 2018). During the polynya years in the 1970s, the volume of surface water entrained at depth in the Weddell Sea was higher than along the continental margin (Gordon, 1982), but the overall contribution of deep convection in AABW formation is highly uncertain (Martinson et al., 1981; Gordon, 1982). Nevertheless, frequent polynya formation during some periods should lead to a higher production of AABW in the Weddell Sea and, potentially, to a modification of its characteristics. It has been speculated that AABW formation because of open-ocean convection was higher during the 1350-1850 period, potentially because of colder conditions at that time, than in the more recent past (Broecker et al., 1999). By contrast, from the analyses of marine records on the southern Chilean margin in the southeast Pacific, Collins et al. (2019) suggest that AABW formation was weaker after 1400 compared with the periods before. Our reconstruction does not suggest such a systematic, longterm shift, but the larger number of polynyas recorded for some periods should have consequences on deep waters that can be detected away from the Weddell Sea.

Our reconstructions provide only a preliminary step whose goal is to stimulate more investigation on the subject. Our target is also limited to polynyas similar to the great Weddell polynya of the 1970s. This implies that we have not addressed the occurrence of smaller polynyas, which may be more frequent, or of open-ocean polynyas with a signature different from the Weddell polynya of the 1970 s - in particular those that may have been present in other sectors of the Southern Ocean.

Despite these limitations, we are still able to reach some conclusions about the frequency of polynya formation. First, polynyas like the one observed in the 1974-1976 period have not been frequent over the past millennium, occurring only a few times per century at most. The mean number of years with open-ocean polynya for the whole period ranges from 1.8 to 3.7 years per century in our three reconstructions (criteria at 0.8 with a value of 1 corresponding to the great Weddell polynya of the 1970s). Second, the sequences of polynya opening tend to last only a few years, with no clear periodicity. Some exceptions may have occurred with high surface mass balance values potentially associated with the formation of polynyas during several decades. Nevertheless, as we go back in time, the uncertainties on the potential processes controlling the precipitation are larger, as are the dating uncertainties. Third, from a more technical point of view, the observed changes associated with polynya formation are similar to those given by global climate models that display realistic open-ocean polynyas in the Weddell Sea, indicating that those models can be used for data assimilation. Thus, this technique is very promising for future reconstructions of polynya activity.
Data availability. Instrumental observations can be obtained from the Met READER site (https://legacy.bas.ac.uk/met/READER/, last access: 9 April 2020, SCAR, 2020; https://doi.org/10.1175/15200442(2004)017<2890:TSRPTA>2.0.CO;2, Turner et al., 2004). The reconstruction of Antarctic surface air temperatures based on instrumental data is available from http: //polarmet.osu.edu/datasets/Antarctic_recon/ (last access: 4 July 2018; Nicolas and Bromwich, 2014, https://doi.org/10.1175/JCLI$\mathrm{D}-13-00733.1) . \quad \delta^{18} \mathrm{O}$ time series are available from the NOAA World Data Center for paleoclimatology data (https://www.ncdc.noaa.gov/paleo-search/study/22589, last access: 18 March 2018, Stenni et al., 2017b). The surface mass balance time series from Thomas (2017, https://doi.org/10.5285/c4ecfe2512f2-453b-ad19-49a19e90ee32) was sourced from https: //data.bas.ac.uk/full-record.php?id=GB/NERC/BAS/PDC/00940

(last access: 19 February 2018), and the reconstruction of Medley and Thomas (2019, https://doi.org/10.1038/s41558018-0356-x) is available from https://earth.gsfc.nasa.gov/ cryo/data/antarctic-accumulation-reconstructions (last access: 6 February 2019). The results of the ECHAM5-wiso simulation covering the 1871-2011 period can be downloaded from https://doi.org/10.5281/zenodo.1249604 (Steiger, 2018). RACMO2 data are available upon request from Jan Lenaerts (jan.lenaerts@Colorado.EDU). The SPEAR-LO and SPEAR-AM2 results are available upon request from Liping Zhang (liping.zhang@noaa.gov). The reconstructions of polynya activity are available from https://doi.org/10.5281/zenodo.4271569 (Goosse et al., 2020).

Author contributions. HG designed the study. QD, MC and HG performed the analysis and made the figures. LZ provided SPEAR model results and advice on their use. All of the authors contributed to the discussion and interpretation of the results. HG led the writing of the paper with contributions from all authors.

Competing interests. The authors declare that they have no conflict of interest.

Acknowledgements. Hugues Goosse is a research director within the F.R.S.-FNRS. Quentin Dalaiden is a research fellow with the Fonds pour la formation á la Recherche dans l'Industrie et dans l'Agronomie (FRIA-Belgium). Liping Zhang is supported through UCAR under block funding from NOAA/GFDL. We would like to thank all of the scientists that collected and shared their ice core records as well Nathan Steiger for sharing the output of the ECHAM5-wiso simulation, Jan Lenaerts for sharing the output of the RACMO simulation, and Rachael Rhodes, Jean-Louis Tison and François Fripiat for stimulating discussions on polynya reconstructions.

Financial support. This research has been supported by the Belgian Research Action through Interdisciplinary Networks (BRAIN.be) from the Belgian Science Policy Office in the framework of the "East Antarctic surface mass balance in the An- 
thropocene: observations and multiscale modelling (Mass2Ant)" project (contract no. BR/165/A2/Mass2Ant).

Review statement. This paper was edited by Erin McClymont and reviewed by two anonymous referees.

\section{References}

Abram, N. J., Wolff, E. W., and Curran, M. A. J.: A review of sea ice proxy information from polar ice cores, Quaternary Sci. Rev., 79, 168-183, https://doi.org/10.1016/j.quascirev.2013.01.011, 2013.

Abram, N. J., Mulvaney, R., Vimeux, F., Phipps, S. J., Turner, J., and England, M. H.: Evolution of the Southern Annular Mode during the past millennium, Nat. Clim. Change, 4, 564-569, https://doi.org/10.1038/nclimate2235, 2014.

Adcroft, A., Anderson, W., Balaji, V., Blanton, C., Bushuk, M., Dufour, C. O., Dunne, J. P., Griffies, S. M., Hallberg, R., J. Harrison, M. J., Held, I. M., Jansen, M. F., John, J. G., Krasting, J. P., Langenhorst, A. R., Legg, S., Liang, Z., McHugh, C., Radhakrishnan, A., Reichl, B. G., Rosati, T., Samuels, B. L., Shao, A., Stouffer, R., Winton, M., Wittenberg, A. T., Xiang, B., Zadeh, N., and Zhang, R.: The GFDL global ocean and sea ice model OM4.0: Model description and simulation features, J. Adv. Model. Earth Sy., 11, 3167-3211, https://doi.org/10.1029/2019MS001726, 2019.

Anderson, J. L., Balaji, V., Broccoli, A. J., Cooke, W. F., Delworth, T. L., Dixon, K. W., Donner, L. J., Dunne, K. A., Freidenreich, S. M., Garner, S. T., Gudgel, R. G., Gordon, C. T., Held, I. M., Hemler, R. S., Horowitz, L. W., Klein, S. A., Knutson, T. R., Kushner, P. J., Langenhost, A. R., Lau, N. C., Liang, Z., Malyshev, S. L., Milly, P. C. D., Nath, M. J., Ploshay, J. J., Ramaswamy, V., Schwarzkopf, M. D., Shevliakova, E., Sirutis, J. J., Soden, B. J., Stern, W. F., Thompson, L. A., Wilson, R. J., Wittenberg, A. T., and Wyman, B. L.: The new GFDL global atmosphere and land model AM2-LM2: Evaluation with prescribed SST simulations, J. Climate, 17, 4641-4673, https://doi.org/10.1175/JCLI-3223.1, 2004.

Badgeley, J. A., Steig, E. J., Hakim, G. J., and Fudge, T. J.: Greenland temperature and precipitation over the last 20000 years using data assimilation, Clim. Past, 16, 1325-1346, https://doi.org/10.5194/cp-16-1325-2020, 2020.

Broecker, W. S., Sutherland, S., and Peng, T.-H.: A possible 20th-century slowdown of Southern Ocean deep water formation, Science, 286, 1132-1135, https://doi.org/10.1126/science.286.5442.1132, 1999.

Campbell, E. C., Wilson, E. A., Moore, G. W. K., Riser, S. C., Brayton, C. E., Mazloff, M. R., and Talley, L. D.: Antarctic offshore polynyas linked to Southern Hemisphere climate anomalies, Nature, 570, 319-325, https://doi.org/10.1038/s41586-019-1294-0, 2019.

Carsey, F. D.: Microwave observation of the Weddell Polynya, Mon. Weather Rev., 108, 2032-2044, https://doi.org/10.1175/15200493(1980)108<2032:MOOTWP>2.0.CO;2, 1980.

Cavitte, M. G. P., Dalaiden, Q., Goosse, H., Lenaerts, J. T. M., and Thomas, E. R.: Reconciling the surface temperature-surface mass balance relationship in models and ice cores in Antarc- tica over the last 2 centuries, The Cryosphere, 14, 4083-4102, https://doi.org/10.5194/tc-14-4083-2020, 2020.

Cheon, W. G., Lee, S.-K., Gordon, A. L., Liu, Y., Cho, C.-B., and Park, J. J.: Replicating the 1970s' Weddell Polynya using a coupled ocean-sea ice model with reanalysis surface flux fields, Geophys. Res. Lett., 42, 5411-5418, https://doi.org/10.1002/2015GL064364, 2015.

Christiansen, B. and Ljungqvist, F. C.: Challenges and perspectives for large-scale temperature reconstructions of the past two millennia, Rev. Geophys., 55, 40-96, https://doi.org/10.1002/2016RG000521, 2017.

Collins, J. A., Lamy, F., Kaiser, J., Ruggieri, N., Henkel, S., De Pol-Holz, R., Garreaud, R., and Arz, H. W.: Centennial-scale SE Pacific sea surface temperature variability over the past 2,300 years, Paleoceanography and Paleoclimatology, 34, 336-352, https://doi.org/10.1029/2018PA003465, 2019.

Comiso, J. C. and Gordon, A. L.: Recurring polynyas over the Cosmonaut Sea and the Maud Rise, J. Geophys. Res., 92, 28192833, https://doi.org/10.1029/JC092iC03p02819, 1987.

Comiso, J. C. and Gordon, A. L.: Cosmonaut polynya in the Southern Ocean: structure and variability, J. Geophys. Res., 101, 18297-18313, https://doi.org/10.1029/96JC01500, 1996.

Criscitiello, A. S., Das, S. B., Evans, M. J., Frey, K. E., Conway, H., Joughin, I., Medley, B., and Steig, E. J.: Ice sheet record of recent sea-ice behavior and polynya variability in the Amundsen Sea, West Antarctica. J. Geophys. Res.-Ocean., 118, 118-130, https://doi.org/10.1029/2012JC008077, 2013.

Dalaiden, Q., Goosse, H., Klein, F., Lenaerts, J. T. M., Holloway, M., Sime, L., and Thomas, E. R.: How useful is snow accumulation in reconstructing surface air temperature in Antarctica? A study combining ice core records and climate models, The Cryosphere, 14, 1187-1207, https://doi.org/10.5194/tc-14-11872020, 2020.

Dätwyler, C., Neukom, R., Abram, N. J., Gallant, A. J. E., Grosjean, M., Jacques-Coper, M., Karoly, D. J., and Villalba, R.: Teleconnection stationarity, variability and trends of the Southern Annular Mode (SAM) during the last millennium, Clim. Dynam., 51, 2321-2339, https://doi.org/10.1007/s00382-017-4015-0, 2018.

de Lavergne, C., Palter, J. B., Galbraith, E. D., Bernardello, R., and Marinova, I.: Cessation of deep convection in the open Southern Ocean under anthropogenic climate change, Nat. Clim. Change, 4, 278-282, https://doi.org/10.1038/nclimate2132, 2014.

Delworth, T. L., Cooke, W. F., Adcroft, A., Bushuk, M., Chen, J.-H., Dunne, K. A., Ginoux, P., Gudgel, R., Hallberg, R. W., Harris, L., Harrison, M.J., Johnson, N., Kapnick, S. B., Lin, S.J., Lu, F., Malyshev, S., Milly, P. C., Murakami, H., Naik, V., Pascale, S. Paynter, D., Rosati, A., Schwarzkopf, M. D., Shevliakova, E., Underwood, S., Wittenberg, A. T., Xiang, B., Yang, X., Zeng, F., Zhang, H., Zhang, L., and Zhao, M.: SPEAR-the next generation GFDL modeling system for seasonal to multidecadal prediction and projection, J. Adv. Model Earth Sy., 12, e2019MS0018952020, https://doi.org/10.1029/2019MS001895, 2020.

de Vernal, A., Gersonde, R., Goosse, H., Seidenkrantz, M.S., and Wolff, E. W.: Sea ice in the paleoclimate system: the challenge of reconstructing sea ice from proxies - An introduction, Quaternary Sci. Rev., 79, 1-8, https://doi.org/10.1016/j.quascirev.2013.08.009, 2013. 
Dubinkina, S. and Goosse, H.: An assessment of particle filtering methods and nudging for climate state reconstructions, Clim. Past, 9, 1141-1152, https://doi.org/10.5194/cp-9-11412013, 2013.

Dufour, C. O., Morrison, A. K., Griffies, S. M., Frenger, I., Zanowski, H., and Winton, M.: Preconditioning of the Weddell Sea polynya by the ocean mesoscale and dense water overflows, J. Climate, 30, 7719-7737, https://doi.org/10.1175/JCLI-D-160586.1, 2017.

Francis, D., Eayrs, C., Cuesta, J., and Holland, D.: Polar cyclones at the origin of the reoccurrence of the Maud Rise Polynya in austral winter 2017, J. Geophys. Res.-Atmos., 124, 5251-5267, https://doi.org/10.1029/2019JD030618, 2019.

Foster, T. D. and Carmack, E. C.: Frontal zone mixing and Antarctic Bottom Water formation in the southern Weddell Sea, Deep Sea Res. Oceanogr. Abstr., 23, 301-317, https://doi.org/10.1016/0011-7471(76)90872-X, 1976.

Franke, J., Brönnimann, S., Bhend, J., and Brugnara, Y.: A monthly global paleo-reanalysis of the atmosphere from 1600 to 2005 for studying past climatic variations, Scientific Data, 4, 170076, https://doi.org/10.1038/sdata.2017.76, 2017.

Goel, V., Matsuoka, K., Berger, C. D., Lee, I., Dall, J., and Forsberg, R.: Characteristics of ice rises and ice rumples in Dronning Maud Land and Enderby Land, Antarctica, J. Glaciol., 66, 1064-1078, https://doi.org/10.1017/jog.2020.77, 2020.

Goosse, H. and Fichefet, T.: Open-ocean convection and polynya formation in a large-scale ice-ocean model, Tellus A, 53, 94-111, https://doi.org/10.1034/j.1600-0870.2001.01061.x, 2001.

Goosse, H., Crespin, E, Dubinkina, S., Loutre, M. F., Mann, M. E., Renssen, H., Sallaz-Damaz, Y., and Shindell, D.: The role of forcing and internal dynamics in explaining the "Medieval Climate Anomaly", Clim. Dynam., 39, 2847-2866, https://doi.org/10.1007/s00382-012-1297-0, 2012.

Goosse, H., Kay, J. E., Armour, K., Bodas-Salcedo, A., Chepfer, H., Docquier, D., Jonko, A., Kushner, P. J., Lecomte, O., Massonnet, F., Park, H.-S., Pithan, F., Svensson, G., and Vancoppenolle, M.: Quantifying climate feedbacks in polar regions, Nat. Commun, 9, 1919, https://doi.org/10.1038/s41467-018-04173-0, 2018.

Goosse, H., Dalaiden, Q., Cavitte, M. G. P., and Zhang, L.: Three reconstructions of the formation of large open ocean polynyas in the Southern Ocean using ice core records, Data set, Zenodo, https://doi.org/10.5281/zenodo.4271569, 2020.

Gordon, A. L.: Deep Antarctic convection west of Maud Rise, J. Phys. Oceanogr., 8, 600-612, https://doi.org/10.1175/15200485(1978)008<0600:DACWOM>2.0.CO;2, 1978.

Gordon, A. L.: Weddell Deep Water variability, J. Mar. Res., 40, 199-217, 1982.

Gordon, A. L. and Huber, B. A.: Southern Ocean winter mixed layer, J. Geophys. Res., 95, 11655-11672, https://doi.org/10.1029/JC095iC07p11655, 1990.

Gordon, A. L., Visbeck, M., and Comiso, J. C.: A possible link between the Weddell Polynya and the Southern Annular Mode, J. Climate, 20, 2558-2571, https://doi.org/10.1175/JCLI4046.1, 2007.

Gorodetskaya, I. V., Tsukernik, M., Claes, K., Ralph, M. F., Neff, W. D., and Van Lipzig, N. P. M.: The role of atmospheric rivers in anomalous snow accumulation in East Antarctica, Geophys. Res. Lett., 41, 6199-6206. https://doi.org/10.1002/2014GL060881, 2014.
Goursaud, S., Masson-Delmotte, V., Favier, V., Preunkert, S., Legrand, M., Minster, B., and Werner, M.: Challenges associated with the climatic interpretation of water stable isotope records from a highly resolved firn core from Adélie Land, coastal Antarctica, The Cryosphere, 13, 1297-1324, https://doi.org/10.5194/tc-13-1297-2019, 2019.

Graf, W., Oerter H., Reinwarth, O., and Stichler, W.: Stable-isotope records from Dronning Maud Land, Antarctica, Ann. Glaciol., 35, 195-201, https://doi.org/10.3189/172756402781816492, 2002.

Hakim, G. J., Emile-Geay, J., Steig, E. J., Noone, D., Anderson, D. M., Tardif, R., Steiger, N., and Perkins, W. A.: The last millennium climate reanalysis project: Framework and first results, J. Geophys. Res.-Atmos., 121, 6745-6764, https://doi.org/10.1002/2016JD024751, 2016.

Heuzé, C., Heywood, K. J., Stevens, D. P., and Ridley, J. K.: Southern Ocean bottom water characteristics in CMIP5 models, Geophys. Res. Lett., 40, 1409-1414, https://doi.org/10.1002/grl.50287, 2013.

Heuzé, C., Heywood, K. J., Stevens, D. P., and Ridley, J. K.: Changes in global ocean bottom properties and volume transports in CMIP5 models under climate change scenarios, J. Climate, 28, 2917-2944, https://doi.org/10.1175/JCLI-D-14$00381.1,2015$.

Holland, D. M.: Explaining the Weddell Polynya - a large ocean eddy shed at Maud Rise, Science, 292 1697-1700, https://doi.org/10.1126/science.1059322, 2001.

Holloway, M. D., Sime, L. C., Singarayer, J. S., Tindall, J. C., Bunch, P., and Valdes, P. J.: Antarctic last interglacial isotope peak in response to sea ice retreat not ice-sheet collapse, Nat. Commun. 7, 12293, https://doi.org/10.1038/ncomms12293, 2016.

Janjić, T., Bormann, N., Bocquet, M., Carton, J. A., Cohn, S. E., Dance, S. L., Losa, S. N., Nichols, N. K., Potthast, R., Waller, J. A., and Weston, P.: On the representation error in data assimilation, Advances in Data Assimilation Methods, Q. J. Roy. Meteor. Soc., 144, 1257-1278, https://doi.org/10.1002/qj.3130, 2018.

Jena, B., Ravichandran, M., and Turner, J.: Recent reoccurrence of large open-ocean polynya on the Maud Rise seamount, Geophys. Res. Let., 46, 4320-4329, https://doi.org/10.1029/2018GL081482, 2019.

Johnson, G. C.: Quantifying Antarctic Bottom Water and North Atlantic Deep Water volumes, J. Geophys. Res., 113, C05027, https://doi.org/10.1029/2007JC004477, 2008.

Jones, P. D., Briffa, K. R., Osborn, T. J., Lough, J. M., van Ommen, T., Vinther, B. M., Luterbacher, J., Zwiers, F. W., Wahl, E., Schmidt, G., Ammann, C., Mann, M. E., Wanner, H., Buckley, B. M., Cobb, K., Esper, J., Goosse, H., Graham, N., Jansen, E., Kiefer, T., Kull, C., Mosley-Thompson, E., Overpeck, J. T., Schulz, M., Tudhope, S., Villalba, R., and Wolff, E.: Highresolution paleoclimatology of the last millennium: a review of the current status and future prospects, The Holocene, 19, 3-49, https://doi.org/10.1177/0959683608098952, 2009.

Kaufman, Z. S., Feldl, N., Weijer, W., and Veneziani, M.: Causal interactions between Southern Ocean polynyas and highlatitude atmosphere-ocean variability, J. Climate, 33, 48914905, https://doi.org/10.1175/JCLI-D-19-0525.1, 2020.

Kaczmarska, M., Isaksson, E., Karlöf, K., Winther, J.-G., Kohler, J., Godtliebsen, F., Ringstad Olsen, L., Hofstede, C. M., van 
den Broeke, M. R., Van DeWal, R. S. W., and Gundestrup, N.: Accumulation variability derived from an ice core from coastal Dronning Maud Land, Antarctica, Ann. Glaciol., 39, 339-345, https://doi.org/10.3189/172756404781814186, 2004.

Klein, F., Abram, N. J., Curran, M. A. J., Goosse, H., Goursaud, S., Masson-Delmotte, V., Moy, A., Neukom, R., Orsi, A., Sjolte, J., Steiger, N., Stenni, B., and Werner, M.: Assessing the robustness of Antarctic temperature reconstructions over the past 2 millennia using pseudoproxy and data assimilation experiments, Clim. Past, 15, 661-684, https://doi.org/10.5194/cp-15661-2019, 2019.

Kurtakoti, P., Veneziani, M., Stössel, A., and Weijer, W.: Preconditioning and formation of Maud Rise polynyas in a highresolution Earth System Model, J. Climate, 31, 9659-9678, https://doi.org/10.1175/JCLI-D-18-0392.1, 2018.

Laepple, T., Münch, T., Casado, M., Hoerhold, M., Landais, A., and Kipfstuhl, S.: On the similarity and apparent cycles of isotopic variations in East Antarctic snow pits, The Cryosphere, 12, 169187, https://doi.org/10.5194/tc-12-169-2018, 2018.

Laluraj, C. M., Thamban, M., Naik, S. S., Redkar, B. L., Chaturvedi, A., and Ravindra, R.: Nitrate records of a shallow ice core from East Antarctica: atmospheric processes, preservation and climatic implications, The Holocene, 21, 351-356, https://doi.org/10.1177/0959683610374886, 2011.

Latif, M., Martin, T., and Park, W.: Southern Ocean sector centennial climate variability and recent decadal trends, J. Climate, 26, 7767-7782, https://doi.org/10.1175/JCLI-D-12-00281.1, 2013.

Lenaerts, J. T. M., Medley, B., van den Broeke, M. R., and Wouters, B.: Observing and modeling ice sheet surface mass balance, Rev. Geophys., 57, 376-420, https://doi.org/10.1029/2018RG000622, 2019.

Levine, J. G., Yang, X., Jones, A. E., and Wolff, E. W.: Sea salt as an ice core proxy for past sea ice extent: A process based model study, J. Geophys. Res.-Atmos., 119, 5737-5756, https://doi.org/10.1002/2013JD020925, 2014.

Lyman, J. M. and Johnson, G. C.: Estimating global ocean heat content changes in the upper $1800 \mathrm{~m}$ since 1950 and the influence of climatology choice, J. Climate, 27, 1945-1957, https://doi.org/10.1175/JCLI-D-12-00752.1, 2014.

Manabe, S., Stouffer, R. J., Spelman, M. J., and Bryan, K.: Transient response of coupled ocean-atmosphere model to gradual changes of atmospheric $\mathrm{CO}_{2}, \mathrm{~J}$. Climate, 4, 785-818, https://doi.org/10.1175/15200442(1991)004<0785:TROACO>2.0.CO;2, 1991.

Mann, M. E., Zhang, Z., Hughes, M. K., Bradley, R. S., Miller, S. K., Rutherford, S., and Ni, F.: Proxy-based reconstructions of hemispheric and global surface temperature variations over the past two millennia, P. Natl. Acad. Sci. USA, 105, 13252-13257, https://doi.org/10.1073/pnas.0805721105, 2008.

Mantyla, A. W. and Reid, J. L.: Abyssal characteristics of the World Ocean waters, Deep-Sea Res. Pt A, 30, 805-833, https://doi.org/10.1016/0198-0149(83)90002-X, 1983.

Marshall, G. J.: Trends in the Southern Annular Mode from observations and reanalyses, J. Climate, 16, 4134-4143, https://doi.org/10.1175/15200442(2003)016<4134:TITSAM>2.0.CO;2, 2003.

Martin, T., Park, W., and Latif, M.: Multi-centennial variability controlled by Southern Ocean convection in the Kiel Climate Model,
Clim. Dynam., 40, 2005-2022, https://doi.org/10.1007/s00382012-1586-7, 2013.

Martinson, D. G.: Evolution of the Southern Ocean winter mixed layer and sea ice: open ocean deepwater formation and ventilation, J. Geophys. Res., 95, 11641-11654, https://doi.org/10.1029/JC095iC07p11641, 1990.

Martinson, D. G., Killworth, P. D., and Gordon, A. L.: A convective model for the Weddell Polynya, J. Phys. Oceanogr., 11, 466-488, https://doi.org/10.1175/15200485(1981)011<0466:ACMFTW>2.0.CO;2, 1981.

Masson-Delmotte, V., Hou, S., Ekaykin, A., Jouzel, J., Aristarain, A., Bernardo, R., Bromwich, D., Cattani, O., Delmotte, M., Falourd, S., Frezzotti, M., Gallée, H., Genoni, L., Isaksson, E., Landais, A., Helsen, M., Hoffmann, G., Lopez, J., Morgan, V., Motoyama, H., Noone, D., Oerter, H., Petit, J., Royer, A., Uemera, R., Schmidt, G., Schlosser, E., Simões, J., Steig, E., Stenni, B., Stievenard, M., van den Broeke, M., van de Wal, R., van de Berg, W., Vimeux, F., and White, J.: A review of Antarctic surface snow isotopic composition: Observations, atmospheric circulation, and isotopic modeling, J. Climate, 21, 3359-3387, https://doi.org/10.1175/2007JCLI2139.1, 2008.

Medley, B. and Thomas, E. R.: Increased snowfall over the Antarctic Ice Sheet mitigated twentieth-century sea-level rise, Nat. Clim. Change, 9, 34-39, https://doi.org/10.1038/s41558-0180356-x, available also from https://earth.gsfc.nasa.gov/cryo/data/ antarctic-accumulation-reconstructions, last access: 6 February 2019.

Medley, B., McConnell, J. R., Neumann, T. A., Reijmer, C. H., Chellman, N., Sigl, M., and Kipfstuhl, S.: Temperature and snowfall in western Queen Maud Land increasing faster than climate model projections, Geophys. Res. Lett., 45, 1472-1480, https://doi.org/10.1002/2017GL075992, 2018.

Meier, W. N., Gallaher, D., and Campbell, G. G.: New estimates of Arctic and Antarctic sea ice extent during September 1964 from recovered Nimbus I satellite imagery, The Cryosphere, 7, 699705, https://doi.org/10.5194/tc-7-699-2013, 2013.

Mezgec, K., Stenni, B., Crosta, X., Masson-Delmotte, V., Baroni, C., Braida, M., Ciardini, V., Colizza, E., Melis, R., Salvatore, M. C., Severi, M., Scarchilli, C., Traversi, R., Udisti, R., and Frezzotti, M.: Holocene sea ice variability driven by wind and polynya efficiency in the Ross Sea, Nat. Commun., 8, 1334, https://doi.org/10.1038/s41467-017-01455-x, 2017.

Moore, G. W. K., Alverson, K., and Renfrew, I. A.: A reconstruction of the air-sea interaction associated with the Weddell Polynya, J. Phys. Oceanogr., 32, 1685-1698, https://doi.org/10.1175/15200485(2002)032,1685:AROTAS.2.0.CO;2, 2002.

Morales Maqueda, M. A., Willmott, A. J., and Biggs, N. R. T.: Polynya dynamics: A review of observations and modeling, Rev. Geophys., 42, RG1004, https://doi.org/10.1029/2002RG000116, 2004.

Mulvaney, R., Oerter, H., Peel, D. A., Graf, W., Arrowsmith, C., Pasteur, E. C., Knight, B., Littot, G. C., and Miners, W. D.: 1000 year ice-core records from Berkner Island, Antarctica, Ann. Glaciol., 35, 45-51, https://doi.org/10.3189/172756402781817176, 2002.

Nicolas J. P. and Bromwich, D. H.: New reconstruction of Antarctic near-surface temperatures: Multidecadal trends and reliability of global reanalyses, J. Clim., 27, 8070-8093, https://doi.org/10.1175/JCLI-D-13-00733.1, reconstructed tem- 
perature data available at: http://polarmet.osu.edu/datasets/ Antarctic_recon/ (last access: 4 July 2018), 2014.

Nishio, F., Furukawa, T., Hashida, G., Igarashi, M., Kameda, T., Kohno, M., Motoyama, H., Naoki, K., Satow, K., Suzuki, K., Morimasa, T., Toyama, Y., Yamada, T., and Watanabe, O.: Annual-layer determinations and 167 year records of past climate of $\mathrm{H} 72$ ice core in east Dronning Maud Land, Antarctica, Ann. Glaciol., 35, 471-479, https://doi.org/10.3189/172756402781817086, 2002.

Oerter, H., Wilhelms, F., Jung-Rothenhäusler, F., Göktas, F., Miller, H., Graf, W., and Sommer, S.: Accumulation rates in Dronning Maud Land, Antarctica, as revealed by dielectric-profiling measurements of shallow firn cores, Ann. Glaciol., 30, 27-34, https://doi.org/10.3189/172756400781820705, 2000.

Philippe, M., Tison, J.-L., Fjøsne, K., Hubbard, B., Kjær, H. A., Lenaerts, J. T. M., Drews, R., Sheldon, S. G., De Bondt, K., Claeys, P., and Pattyn, F.: Ice core evidence for a 20th century increase in surface mass balance in coastal Dronning Maud Land, East Antarctica, The Cryosphere, 10, 2501-2516, https://doi.org/10.5194/tc-10-2501-2016, 2016.

Purkey, S. G., Smethie Jr., W. M., Gebbie, G., Gordon, A. L., Sonnerup, R. E., Warner, M. J., and Bullister, J. L.: A synoptic view of the ventilation and circulation of Antarctic Bottom Water from chlorofluorocarbons and natural tracers, Annu. Rev. Mar. Sci., 10, 503-527, https://doi.org/10.1146/annurev-marine121916-063414, 2018.

Rayner, N. A., Parker, D. E., Horton, E. B., Folland, C. K., Alexander, L. V., Rowell, D. P., Kent, E. C., and Kaplan, A.: Global analyses of sea surface temperature, sea ice, and night marine air temperature since the late nineteenth century, J. Geophys. Res., 108, 4407, https://doi.org/10.1029/2002JD002670, 2003.

Resplandy, L., Keeling, R. F., Eddebbar, Y., Brooks, M. K., Wang, R., Bopp, L., Long, M. C., Dunne, J. P., Koeve, W., and Oschlies, A.: Quantification of ocean heat uptake from changes in atmospheric $\mathrm{O}_{2}$ and $\mathrm{CO}_{2}$ composition, Scientific Reports, 9, 20244, https://doi.org/10.1038/s41598-019-56490-z, 2019.

Rhodes, R. H., Bertler, N. A. N., Baker, J. A., Sneed, S. B., Oerter, H., and Arrigo, K. R.: Sea ice variability and primary productivity in the Ross Sea, Antarctica, from methylsulphonate snow record, Geophys. Res. Lett., 36, L10704, https://doi.org/10.1029/2009GL037311, 2009.

Rhodes, R. H., Yang, X., and Wolff, E. W.: Sea ice versus storms: What controls sea salt in Arctic ice cores?, Geophys. Res. Lett., 45, 5572-5580, https://doi.org/10.1029/2018GL077403, 2018.

Sallée, J.-B., Shuckburgh, E., Bruneau, N., Meijers, A. J. S., Bracegirdle, T. J., Wang, Z., and Roy, T.: Assessment of Southern Ocean water mass circulation and characteristics in CMIP5 models: Historical bias and forcing response, J. Geophys. Res.Oceans, 118, 1830-1844, https://doi.org/10.1002/jgrc.20135, 2013.

SCAR (Scientific Committee on Antarctic Research): Met READER: READER data set, British Antarctic Survey (BAS), Cambridge, UK, available at: https://legacy.bas.ac.uk/ met/READER/, last access: 9 April 2020.

Sime, L. C., Tindall, J. C., Wolff, E. W., Connolley, W. M., and Valdes, P.: Antarctic isotopic thermometer during a CO2 forced warming event, J. Geophys. Res., 113, D24119, https://doi.org/10.1029/2008JD010395, 2008.
Sommer, S., Appenzeller, C., Rothlisberger, R., Hutterli, M. A., Stauffer, B., Wagenbach, D., Oerter, H., Wilhelms, F., Miller, H., and Mulvaney, R.: Glacio-chemical study spanning the past $2 \mathrm{kyr}$ on three ice cores from Dronning Maud Land, Antarctica 1. Annually resolved accumulation rates, J. Geophys. Res., 105, 29411-29421, https://doi.org/10.1029/2000JD900449, 2000.

Steig, E. J., Ding, Q., White, J. W. C., Küttel, M., Rupper, S. B., Neumann, T. A., Neff, P. D., Gallant, A. J. E., Mayewski, P. A., Taylor, K. C., Hoffmann, G., Dixon, D. A., Schoenemann, S. W., Markle, B. R., Fudge, T. J., Schneider, D. P., Schauer, A. J.,Teel, R. P., Vaughn, B. H., Burgener, L., Williams, J., and Korotkikh, E.: Recent climate and icesheet changes in West Antarctica compared with the past 2,000 years, Nat. Geosci., 6, 372375, https://doi.org/10.1038/ngeo1778, 2013.

Steiger, N. J.: Historical climate model output of ECHAM5wiso from 1871-2011 at T106 resolution, Data set, Zenodo, https://doi.org/10.5281/zenodo.1249604, 2018.

Steiger, N. J., Steig, E. J., Dee, S. G., Roe, G. H., and Hakim, G. J.: Climate reconstruction using data assimilation of water isotope ratios from ice cores, J. Geophys. Res.-Atmos., 122, 1545-1568, https://doi.org/10.1002/2016JD026011, 2017.

Steiger, N. J., Smerdon, J. E., Cook, E. R., and Cook, B..: A reconstruction of global hydroclimate and dynamical variables over the Common Era, Scientific Data, 5, 180086, https://doi.org/10.1038/sdata.2018.86, 2018.

Stenni, B., Curran, M. A. J., Abram, N. J., Orsi, A., Goursaud, S., Masson-Delmotte, V., Neukom, R., Goosse, H., Divine, D., van Ommen, T., Steig, E. J., Dixon, D. A., Thomas, E. R., Bertler, N. A. N., Isaksson, E., Ekaykin, A., Werner, M., and Frezzotti, M.: Antarctic climate variability on regional and continental scales over the last 2000 years, Clim. Past, 13, 1609-1634, https://doi.org/10.5194/cp-13-1609-2017, 2017a.

Stenni, B., Curran, M. A. J., Abram, N. J., Orsi, A. J., Goursaud, S., Masson-Delmotte, V., Neukom, R., Goosse, H., Divine, D. V., van Ommen, T. D., Steig, E. J., Dixon, D. A., Thomas, E. R., Bertler, N. A. N., Isaksson, E., Ekaykin, A. A., Werner, M., and Frezzotti, M.: PAGES Antarctica2k Temperature Reconstructions, Data set, NOAA, available at: https://www.ncdc.noaa.gov/ paleo-search/study/22589 (last access: 18 March 2018), $2017 \mathrm{~b}$.

Stössel, A. and Kim, S.-J.: Decadal deep-water variability in the subtropical Atlantic and convection in the Weddell Sea, J. Geophys. Res., 106, 22425-22440, https://doi.org/10.1029/2000JC000335, 2001.

Stössel, A., Notz, D., Haumann, F. A., Haak, H., Jungclaus, J., and Mikolajewicz, U.: Controlling high-latitude Southern Ocean convection in climate models, Ocean Modell., 86, 58-75, https://doi.org/10.1016/j.ocemod.2014.11.008, 2015.

Swart, S., Johnson, K., Mazloff, M. R., Meijers, A., Meredith, M. P., Newman, L., and Sallée, J.-B.: Return of the Maud Rise polynya: climate litmus or sea ice anomaly?, in: State of the Climate in 2017, B. Am. Meteorol. Soc., 99, S188-S189, https://doi.org/10.1175/2018BAMSStateoftheClimate.1, 2018.

Timmermann, R., Lemke, P., and Kottmeier, C.: Formation and maintenance of a polynya in the Weddell Sea, J. Phys. Oceanogr., 29, 1251-1264, https://doi.org/10.1175/15200485(1999)029<1251:FAMOAP>2.0.CO;2 1999.

Thomas, E. R.: Antarctic regional snow accumulation composites over the past 1000 years, Version 1, Data Set, Polar Data Centre, Natural Environment Research Coun- 
cil, $\quad$ https://doi.org/10.5285/c4ecfe25-12f2-453b-ad1949a19e90ee32, sourced from https://data.bas.ac.uk/full-record. php?id=GB/NERC/BAS/PDC/00940 (last access: 19 February 2018), 2017.

Thomas, E. R., van Wessem, J. M., Roberts, J., Isaksson, E., Schlosser, E., Fudge, T. J., Vallelonga, P., Medley, B., Lenaerts, J., Bertler, N., van den Broeke, M. R., Dixon, D. A., Frezzotti, M., Stenni, B., Curran, M., and Ekaykin, A. A.: Regional Antarctic snow accumulation over the past 1000 years, Clim. Past, 13, 1491-1513, https://doi.org/10.5194/cp-13-1491-2017, 2017.

Thomas, E. R., Allen, C. S., Etourneau, J., King, A. C. F., Severi, M., Winton, V. H. L., Mueller, J., Crosta, X., and Peck, V. L.: Antarctic sea ice proxies from marine and ice core archives suitable for reconstructing sea Ice over the past 2000 Years, Geosciences, 9, 506, https://doi.org/10.3390/geosciences9120506, 2019.

Turner, J., Colwell, S. R., Marshall, G. J., Lachlan-Cope, T. A., Carleton, A. M., Jones, P. D., Lagun, V., Reid, P. A., and Iagovkina, S.: The SCAR READER project: Toward a highquality database of mean Antarctic meteorological observations, J. Climate, 17, 2890-2898, https://doi.org/10.1175/15200442(2004)017<2890:TSRPTA>2.0.CO;2, 2004.

Turner, J., Phillips, T., Thamban, M., Rahaman, W., Marshall, G. J., Wille, J. D., Vincent, V., Winton, V. Holly, L., Thomas, E., Wang, Z., van den Broeke, M., Hosking, J. S., and LachlanCope, T.: The dominant role of extreme precipitation events in Antarctic snowfall variability, Geophys. Res. Let., 46, 35023511, https://doi.org/10.1029/2018GL081517, 2019.

van Wessem, J. M., van de Berg, W. J., Noël, B. P. Y., van Meijgaard, E., Amory, C., Birnbaum, G., Jakobs, C. L., Krüger, K., Lenaerts, J. T. M., Lhermitte, S., Ligtenberg, S. R. M., Medley, B., Reijmer, C. H., van Tricht, K., Trusel, L. D., van Ulft, L. H., Wouters, B., Wuite, J., and van den Broeke, M. R.: Modelling the climate and surface mass balance of polar ice sheets using RACMO2 Part 2: Antarctica (1979-2016), The Cryosphere, 12, 1479-1498, https://doi.org/10.5194/tc-12-1479-2018, 2018.

von Berg, L., Prend, C. J., Campbell, E. C., Mazloff, M. R., Talley, L. D., and Gille, S. T.: Weddell Sea phytoplankton blooms modulated by sea ice variability and polynya formation, Geophys. Res. Let., 47, e2020GL087954, https://doi.org/10.1029/2020GL087954, 2020.
Weijer, W., Veneziani, M., Stössel, A., Hecht, M. W., Jeffery, N., Jonko, A., Hodos, T., and Wang, H.: Local atmospheric response to an open-ocean polynya in a high-resolution climate model, J. Climate, 30, 1629-1641, https://doi.org/10.1175/JCLI-D-160120.1, 2017.

Wilson, E. A., Riser, S. C., Campbell, E. C., and Wong, A. P. S.: Winter upper-ocean stability and ice-ocean feedbacks in the sea ice-covered Southern Ocean, J. Phys. Oceanogr., 49, 1099-1117, https://doi.org/10.1175/JPO-D-18-0184.1, 2019.

Zanowski, H., Hallberg, R., and Sarmiento, J. L.: Abyssal ocean warming and salinification after Weddell Polynyas in the GFDL CM2G coupled climate model, J. Phys. Oceanogr., 45, 27552772, https://doi.org/10.1175/JPO-D-15-0109.1, 2015.

Zhang L., Delworth, T. L., Cooke, W., and Yang, X.: Natural variability of Southern Ocean convection as a driver of observed climate trends, Nat. Clim Change, 9, 59-65, https://doi.org/10.1038/s41558-018-0350-3, 2019.

Zhang L., Delworth, T. L., Cooke, W., Goosse, H., Mitchell, B., Morioka, Y., and Yang, X.: On the mean state dependence of Southern Ocean low frequency internal variability, J. Climate, 1-60, https://doi.org/10.1175/JCLI-D-20-0049.1, 2020.

Zhao, M., Golaz, J.-C., Held, I. M., Guo, H., Balaji, V., Benson, R., Chen, J.-H., Chen, X., Donner, L. J., Dunne, J. P., Dunne, K. A., Durachta, J., Fan, S.-M., Freidenreich, S. M., Garner, S. T., Ginoux, P., Harris, L. M., Horowitz, L. W., Krasting, J. P., Langenhorst, A. R., Liang, Z., Lin, P., Lin, S.-J., Malyshev, S., Mason, E., Milly, P. C. D., Ming, Y., Naik, V., Paulot, F., Paynter, D., Phillipps, P., Radhakrishnan, A., Ramaswamy, V., Robinson, T., Schwarzkopf, D., Seman, C. J., Shevliakova, E., Shen, Z., Shin, H., Silvers, L., Wilson, J. R., Winton, M., Wittenberg, A. T., Wyman, B., and Xiang, B.: The GFDL global atmosphere and land model AM4.0/LM4.0: 2. Model description, sensitivity studies, and tuning strategies, J. Adv. Model. Earth Sy., 10, 735-769, https://doi.org/10.1002/2017MS001209, 2018.

Zwally, H. J., Comiso, J. C., Parkinson, C. L., Campbell, W. J., Carsey, F. D., and Gloersen, P.: Antarctic sea ice, 1973-1976: Satellite passive-microwave observations, NASA Spec. Publ., SP-459, 206 pp., available at: https://ntrs.nasa.gov/archive/nasa/ casi.ntrs.nasa.gov/19840002650.pdf (last access: 21 December 2020), 1983. 